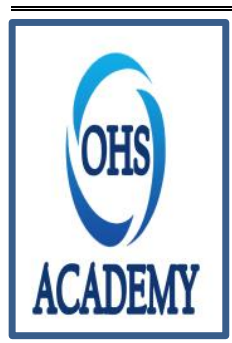

OHS ACADEMY

iş Sağlığı ve Güvenliği Akademi Dergisi

Açık Erişim

Journal of Occupational Health and Safety Academy

Open Access

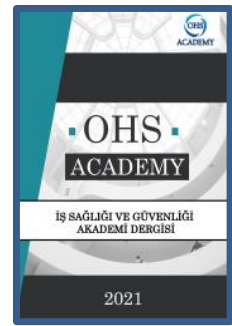

e-ISSN: 2630-578X

\title{
Çay Toplama İşlerinin İş Sağlığı ve Güvenliği Açısından Değerlendirilmesi
}

\author{
Turgay Parlak ${ }^{1}$
}

${ }^{1}$ Endüstri Mühendisliği Bölümü, Fen Bilimleri Enstitüsü, Yıldız Teknik Üniversitesi, İstanbul, Türkiye

Makale Tarihçesi

Gönderim: $\quad 29.01 .2021$

Kabul: $\quad 24.08 .2021$

Yayım: $\quad 31.08 .2021$

Araștırma Makalesi
Öz- Ülkemizin endemik türlerinden olan çay, yaz aylarında üç sürgün halinde toplanmaktadır. Doğu Karadeniz bölgesine ait bu ürünün toplanması ağır bir iş aktivitesini gerektirmektedir. Bu kapsamda yapılan faaliyetlerin iş sağlı̆̆ı ve güvenliği açısından değerlendirilmesi önem arz etmektedir.

Çay toplama işleri aile bireyleri tarafından gerçekleştirilen bir etkinliktir. Ancak yaşanan Covid-19 salgını, toplama işinin zorluğu, yeni neslin başka şehirlerde veya bulundukları yerlerde iş hayatına atılmaları nedeniyle çay toplama işlerinde değişimin yaşanabileceği sinyallerini vermektedir.

$\mathrm{Bu}$ çalışmada aktif olarak çay toplama işlemi gerçekleştirilmiştir. Çay toplamanın geçmişten günümüze gelişimi üzerinde durulmuş, iş sağlığı ve güvenliği adına değerlendirmelerde bulunulmuştur.

İlerleyen dönemlerde bir iș koluna dönüșebilecek bu faaliyetteki tehlikelerin belirlenmesi, çalısanların bilinçlendirilmesi ve bu alana özgü yaklaşımların belirlenmesi adına yararlı olabilecek bir çalışma yapılarak literatüre kazandırılması amaçlanmıștır.

Anahtar Kelimeler - Çay, çay hasadı, çay tarlası, iş sağlı̆̆l ve güvenliği, tarım

\section{Evaluation of Tea Collection Works in Terms of Occupational Health and Safety}

\section{Turgay Parlak ${ }^{1}$}

\footnotetext{
${ }^{1}$ Industrial Engineering Department, Graduate School of Science and Engineering, Yildiz Technical
} University, İstanbul, Turkey

\section{Article History \\ Received: $\quad 00.00 .2020$ \\ Accepted: $\quad 00.00 .2020$ \\ Published: $\quad 00.00 .2020$}

Research Article

\begin{abstract}
Tea, which is one of the endemic species of our country, is collected in three shoots during the summer months. The collection of this product belonging to the Eastern Black Sea region requires a heavy work activity. It is important to evaluate the activities carried out in this context in terms of occupational health and safety.

Tea collecting is an activity performed by family members. However, the Covid-19 epidemic signals that there may be a change in tea collection due to the difficulty of collecting, the new generation entering business life in other cities or where they are located.

In this study, tea collection was actively carried out. The development of tea harvesting from the past to the present has been emphasized and evaluations have been made on behalf of Occupational Health and safety. It is aimed to determine the dangers in this activity, which may turn into a line of work in the future, to raise awareness of employees and to bring them to the literature by conducting a study that may be useful in the name of determining approaches specific to this area.
\end{abstract}

Keywords - Agriculture, occupational health and safety, tea, tea harvest, tea plantation 


\section{Giriş}

Çay başta Çin ve Hindistan olmak üzere Asya kıtasında yer alan ülkelerde yaygın olarak tarımı yapılmakla birlikte, 1988-89 yıllarından itibaren ülkemizde de üretim denemelerine başlanmıştır (Zihnioğlu, 1998). İlerleyen dönemlerde yasal düzenlemeler yapılmış (Saklı, 2019), 19 Aralık 1984 tarihinde resmî gazetede yayımlanan 3092 sayılı Çay Kanunu ile çay tarımı, üretimi, işlenmesi ve satışı serbest hale gelmiş ve özel sektörün faaliyetlere başlaması sağlanmıştır (DPT, 2001).

ÇAYKUR tarafından hazırlanan raporda Türkiye'nin, üretim açısından 234 bin 092 ton ile beşinci sırada, 2018 yılı için kişi başı ortalama 3 bin 200 kilogram tüketimle ilk sırada yer aldığı belirtilmektedir (ÇAYKUR, 2019). $\mathrm{Bu}$ tüketim yaklaşık olarak, günlük 245 milyon bardak, y1llık ise kişi başı bin 250 bardak çaya denk gelebilmektedir (Trabzon Ticaret Borsası, 2018).

Çay üretimi tarımsal faaliyetler kapsamında değerlendirilmektedir. Üretim günümüze kadar aile fertleri tarafından, aile işletmeciliği şeklinde gerçekleştirilmektedir (DPT, 2001). Günlük yevmiye veya kesilen yaş çayın ton başına değerlendirilip ücretlendirilmesi yöntemiyle de çay toplama ișlemi gerçekleștirilmektedir. Bu işler yöre halkından olabileceği gibi mevsimlik tarım işçisi kapsamında yurt içi veya yurt dışından gelen kişilerce yapılmaktadır (Tatoğlu, 2019).

Resmî Gazete'de 29.12.2012 tarih ve 28512 sayı numarası ile yayımlanan, İş Sağlı̆̆ı Ve Güvenliği Risk Değerlendirmesi Yönetmeliği kapsamında çalışma ortamındaki fiziksel, kimyasal, biyolojik, psikososyal, ergonomik risk etmenleri ve benzeri tehlike kaynaklarından oluşan veya bunların etkileşimi sonucu ortaya çıkabilecek tehlikeler belirlenerek, çay tarımı uygulamaları için değerlendirmeler yapılmaya çalışılmıştır.

\section{Literatür Taraması}

Çay ve Bahçe Kültürleri Araştırma Enstitüsü Müdürlüğü, 1924 yılında "Narenciye Fidanlığı" olarak Zihni DERIN tarafından kuruldu. Kuruluş amacı Rize'de findık, portakal, limon, mandalina ve çay yetiştirilmesini sağlamak ve geliştirmekti. 1945 'de "Bahçe Kültürleri İstasyonu" adını almıştır. 1958'de ismi "Çay Araştırma Enstitüsü Müdürlüğü" olarak değiş̧tirilmiş ve Tarım Bakanlığına bağlanmıştır. 1997 yılından sonra ise "Atatürk Çay ve Bahçe Kültürleri Araştırma Enstitüsü Müdürlüğü” olarak faaliyetlerine devam etmektedir. Çayın mamul ürün haline getirilmesi konusundaki çalışmalarda yer almakta, üretim sürecinde çay sektörü ile ilgili ortaya çıkan bilimsel, ekonomik ve sosyal sorunların çözümü konusunda çalışmalar yapmaktadır (ÇAYKUR, ).

Avrupa Birliği ve Türkiye Cumhuriyeti tarafindan finanse edilen ve 2018 yılında kurulan Çay Araştırma ve Uygulama Merkezi (ÇAYMER) Rize ve çevre bölgelerdeki çay endüstri faaliyetleri destekleme, üretim ve ürün kalitesinin artırılması ve kurumsal gelişim görevini üstlenmiştir (ÇAYMER, 2018). Üretimde ve hasatta uygun makinelerin kullanımı ve sürecin iyileştirilmesi konuları üzerinde durulmaktadır.

Recep Tayyip Erdoğan Üniversitesi bünyesinde, 2017 yılında 30205 sayılı Resmi Gazete 'de yayımlanan yönetmelik ile Çay ve Çay Ürünleri Uygulama ve Araştırma Merkezi kurulmuştur. Merkez görevleri arasında çay konusunda araştırmalar yapmak, projelere, bilimsel ve akademik çalı̧̧malara destek olmak, idari ve yasal düzenlemeler katkıda bulunmak, çay üretimi, bakımı, hasadı gibi konularda faaliyetler yürütmektir (Çay Araştırma, 2018). Çay çalışma grubu oluşturulmuş, 2018 yılında hazırladığı yayında, üniversite bünyesinde görev yapan öğretim elemanlarını çay ile ilgili bilimsel yayınlarını bir araya toplayıp derlemiştir.

Milli Prodüktivite Merkezi tarafından 2008 yılında Çay Sektörü Swot Analizi gerçekleştirerek yayınlamıştır. Bu yayında sektörün güçlü ve zayıf yönleri, firsat ve tehditler geniş bir katılımcı kitle ile değerlendirilmiştir. Sonuç önerilerinde koordinasyon kurulu (özel sektör, kamu, sivil toplum kuruluşları) kurularak belirlenen hususlarda önceliklendirme ve değerlendirme yapılması ve eylem planı hazırlanmasının öneminden bahsedilmiştir.

Çay İşletmeleri Genel Müdürlüğü 1982 yılında başladığı faaliyetlerini günümüzde de aktif olarak yürütmektedir. Üreticilerin ve üretimin desteklenmesi, kontrol altında tutulması, kalite, verim ve işletme tekniklerinin geliştirilmesi, üretimde oluşan yan ürünlerin değerlendirilmesi gibi konularda, Türkiye'nin tarım politikasına uygun şekilde çay tarımının geliştirilmesini amaçlayan faaliyetlerde bulunmaktadır. Çay ile ilgili bülten hazırlanması, istatistik ve faaliyet raporlarının hazırlanması, ARGE çalışmaları ve performans raporlarının hazırlanması gibi geniş bir faaliyet alanı vardır.

Karabacak (2017), tarafından gerçekleştirilen "Çay ve Fındık Tarımı Çalışanlarında İş Sağlığı Güvenliği Risklerinin Değerlendirilmesi ve Rehber Geliştirme Çalışması" uzmanlık tezinde, Karadeniz bölgesinin aktif faaliyetleri olan çay ve fındık tarımının iş sağlığı ve güvenliği açısından ayrıntılı bir değerlendirmesini içermekte, tehlikeler tespit edilerek bunlara karşı önerilerde bulunulmaktadır. 
Bülbül ve Aydın (2020), çay toplama işi yapan bir çalışanın bilek gücüne dayanan çay makası kullanarak yaptığı çay hasadı miktarını, makine yardımıyla günlük olarak daha fazla çay hasadı yapabileceğini ifade etmişlerdir. Ayrıca kullanılan benzinli makinelerin egzoz gazlarının çayla teması halinde ortaya çıkabilecek sağlık problemlerine dikkat çekmiş, egzoz çıkış emisyonlarının ölçülmesi gerekliliğinden bahsetmiştir.

Aslanyürek (2019), tez çalışmasında çay tarımı işlerinde fiziksel ve ergonomik risklere karşı eğitim verilmesinin öneminden bahsedilmiştir. Katılımcılara yapılan ön test ve son test puanlarının farklı oluşu onlara verilen eğitimlerinin pozitif katkısı olarak yorumlanmıştır.

Abacı ve arkadaşları (2020), yaptıkları bir çalışmada çay yetiştiriciliğinin bölgede önemli bir yeri olduğu belirtmiş ve yeni bir üretim yaklaşımı yapılarak organik tarım denenmesinin üzerinde durmuştur. Organik tarımda kimyasal gübrelerden uzak durulmasının çalışanların sağlığı kadar çevrenin korunmasına da katkısı olacağından söz edilmiştir. Çiftçilerin ekonomik endişelerinin giderilmesinin organik üretim üzerinde olumlu sonuç doğurduğunu belirtmişlerdir.

Durmuş (2020), yaptı̆̆ çalışmada çay hasadında ergonomik risk faktörlerinin etkili olduğunu, endüstriyel uygulamalarda ergonomik ve fiziksel risk faktörlerinin önemli olduğundan söz etmektedir.

Önçırak (2019), çalışmasında çay üretiminin önemli bir gelir kaynağı olduğu, arazi yapısı ve toprak özelliği nedeniyle diğer üretimlerin yetişmesini zorlaştırdığını belirtmektedir.

Güneroğlu ve Acar (2016), çay üretim alanlarının yeniden dizayn edilmesinin, gerçekleştirilecek peyzaj çalışmalarının arazi yapısının korunması, çekici bir görüntü oluşturması, sürdürülebilir tarım açısından katkısı olabileceğini belirtmektedir. Yapılacak düzenlemelerin tarım turizmini canlandırabileceği ve ekonomik kazanç sağlanabileceği üzerinde durulmuştur. Bu açıdan değerlendirdiğimizde günümüzde Rize ve çevre bölgelerdeki şehirlerde oluşturulan bahçeler yerli turistler tarafından ziyaret edilebilecek alanlar olarak değerlendirilmektedir (Şekil-6).
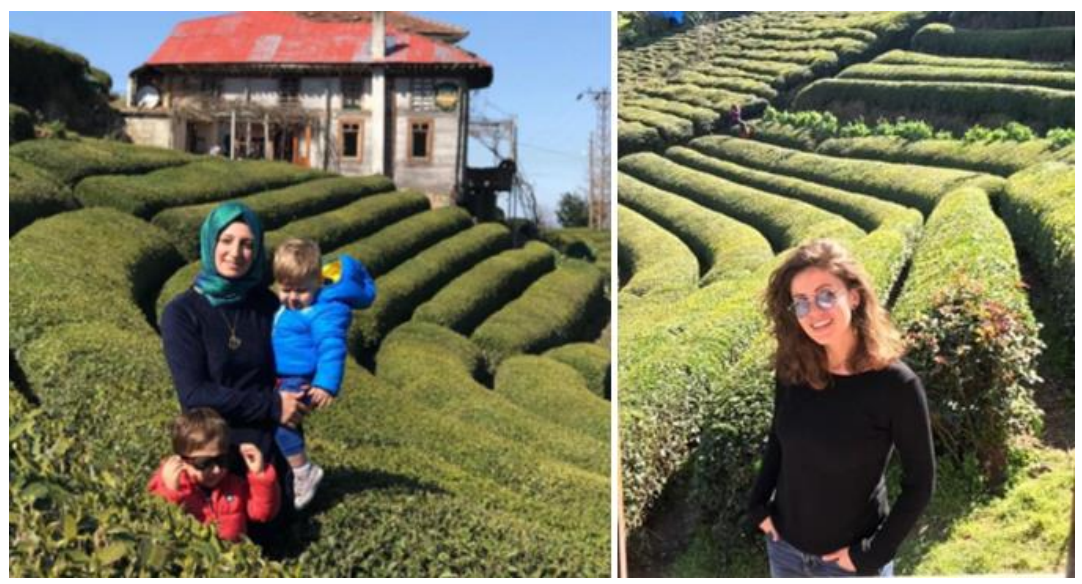

Şekil-1: Görsel Katkı- Tarım Turizmi

Tekeli (2014), çalışmasında Rize'nin çay tarımı için uygun olduğunu ancak çay tarımının oldukça zahmetli bir çalışmayı içerdiğini belirtmiştir.

Engin (2017), çalışmasında çay üretiminde çalışmak için ülkemize gelen Gürcü işçilerin hem çalışma koşulları hem yaşam koşulları hem de sosyal ortam açısından yaşadıkları sorunları belirtmiş ve çözüm önerileri sunmaya çalışmıştır.

Tatoğlu (2019), yaptığı çalışmada mevsimlik tarım işçiliği yapan Türk ve Gürcistan uyruklu işçilerin karşılaştıkları iletişim sorunlarının benzerlikleri ve farklılıklarını değerlendirmiştir. Ailesinden uzak olan çalışanların çevreyle iletişimde zorluk yaşadıkları, güncel olaylar hakkında bilgi edinme adına zorluk yaşadıkları, kendi aileleri hakkında (düğün, hastalık vb.) bilgi sahibi olamadıkları veya gerçekleşmesi durumunda orada bulunamadıkları gibi dezavantajlara sahip olduklarını ifade etmektedir. Ayrıca iş kazası yaşandığında kiminle irtibat kuracağını bilemediklerini ancak hastane acil servislerinde tedavi olabildiklerini ifade etmektedir.

Kaya ve Özgülnar (2015), çalışmalarında mevsimlik tarım işçilerinin yaşam koşulları ve sağlık durumlarını incelemiş, ulaşım, barınma, ücretlendirme, sosyal güvenlik hakları gibi konularda yaşanan olumsuzluklardan bahsetmişlerdir.

Koday (2000), çalışmasında çay tarımı sayesinde Doğu Karadeniz'in çehresini değiştirdiği, sosyo-ekonomik bakımdan bölgenin gelişmesine katkıda bulunduğu belirtilmiştir. 
Yormaz (2018), çalışmasında çay tarımının bölge ekonomisini önemli bir katkı yaptığından söz etmektedir. Çay sayesinde Rize'nin bir marka haline geldiği belirtilmektedir.

Gamze ve Aydın (2017), hazırladıkları çalışmalarında çay üreticilerine alternatif çalışma alanları yaratılarak, çay üreticisi sayısının azaltılması ve verasetle bölünmenin engellenmesi gerekliliğini belirtmiş, çay üretim faaliyetinin karlı bir hale getirecek uygulamalara yönelmenin yapılacak 1slah çalışmalarına katkıda bulunacağının üzerinde durmuşlardır.

Akbulut ve Bakoğlu (2017), yaptıkları çalışmalarında, üreticilerin üretimden satışa kadar sürede oluşan fireden ve uygulanan çay alım kotasından, çay alımı yapanların ise uygun olmayan toplama yöntemleri, hasat sonrası bekleme ve nakliye işlemleri nedeniyle çay kalitesinin düşük fire oranının yüksek olmasından yana şikayetçi olduğu belirlenmiştir.

Uzun (2019), tez çalışmasında, çay tarımında çalışan kadınların emeğini değerlendirmiştir. Çay tarımında aktif iş gücüne katılım sağladıkları, yarıcı olarak işçi çalıştırılması durumunda da üzerlerine ilave ev işi yükü bindiği, elde edilen gelirden pay alamadığ 1 gibi olumsuz durumlardan bahsetmektedir. Ayrıca \%80 oranında iş kazası geçirme oranına sahip oldukları ve bel fitığı, kas iskelet sistemi rahatsızlıkları gibi rahatsızlıklara sahip oldukları belirtilmektedir.

Mirbod ve arkadaşları (1995), yaptıkları çalışmada, kırsal kesimde tarım çalışanlarının karşılaştığı sağlık ve güvenlik tehlikelerinin büyüklüğünün tam olarak bilinmediği belirtmiş ve yeşil çay toplayan işçilerin maruz kaldığı ergonomik zorlanmalar, titreşim, gürültü ve toz etkenleri üzerine araştırma yapmışlardır.

Iqbal ve arkadaşları (2016) yılında yaptıkları çalışmada Bangladeş’te çay tarımı yapan işçilerin mesleki sağlık tehlikelerinin kontrolü ve önlenmesi üzerine değerlendirmelerde bulunmuşlardır.

Phiri (2011), Malavi Cumhuriyetinde yer alan çay bahçelerinde çalışanların iş sağlı̆̆ı ve güvenliğine yönelik bilgi, tutum ve davranışlarını değerlendirmek için bir çalışma yapmıştır.

Toklu ve Ustaahmetoğlu (2016), organik çay üretimi ve pazar araştırmasına yönelik yaptıkları çalışmada çay üretiminde devlet teşvikinin önemli olduğu, katma değeri yüksek ürünlere yönlendirme yapılmasının gerekli olduğunu belirtmektedir.

Çay ülkemiz ve özellikle üretimi yapılan yöreler adına önemli bir maddedir. Çay, literatür taramasında belirtilenlerin yanı sıra fabrikalarda işleme aşamaları, besin içeriğgi, kullanım çeşitliliği, üretim sonrası oluşan atıkların değerlendirilmesi olarak da çok sayıda çalışmaya konu olmuştur. Bu çalışmanın iş sağlığı ve güvenliği açısından yapılan çalışmalarla birlikte literatürde yer alması, ilerleyen dönemlerde daha profesyonel anlamda üretim yapılması, üreticilerin tehlikeler konusunda daha da bilinçli hale gelmesi, otomasyon şartlarının değerlendirilmesi adına literatüre katkı sağlayacaktır.

\section{Materyal ve Yöntem}

Yapılan bu çalışmada Trabzon'un Of ilçesinde yer alan çay bahçesinde fiili olarak çalışma gerçekleştirilerek, çalışma ortamı, çalışma şekli ve maruz kalınabilecek tehlikeler, iş sağlığı ve güvenliği açısından değerlendirilmeye çalışılmıştır.

Çay tarımı çeşitli aşamalara bölünmüş ve her aşamada işin yapılış şekli, karşılaşılabilecek tehlikeler belirtilmiştir. Balık kılçı̆̆ı diyagramı kullanılarak çalışanlar adına tehlikeli olabilecek etkenler ve nedenler belirtilmeye çalışılmıştır. İş Sağlığı Ve Güvenliği Risk Değerlendirmesi Yönetmeliği kapsamında çalışma ortamındaki fiziksel, kimyasal, biyolojik, psikososyal, ergonomik risk etmenleri ve diğer tehlikeler, üretim aşamaları için belirtilmiştir.

Çay üretiminde iş sağlı̆̆ ve güvenliği ile ilgili çalışmaları içeren geniş bir literatür taraması yapılmıştır.

$\mathrm{Bu}$ çalışma ile ilerleyen dönemlerde daha profesyonel anlamda üretim dalına kavuşabilecek çay toplama işlerinin iş sağlığı ve güvenliği alanında daha güvenli bir hale getirilebilmesi, modernizasyon katkısının ve çalışanların bilinçlendirilmesinin sağlanabilmesi için bir basamak olması amaçlanmıştır.

\section{4. Çay Bahçesinde Gerçekleştirilen Faaliyetlerin İş Sağlığı ve Güvenliği Bakımından Değerlendirilmesi}

Çay tarımı faaliyetleri esnasında, çalışanların maruz kalabileceği pek çok tehlikeli durum ve davranış şekillerini içermektedir. Tehlikelerin belirlenmesi ve risklerin değerlendirilmesi işlemlerinde, diğer faaliyet dallarında olduğu gibi çay tarımında da üretimin aşamalara ayrılarak değerlendirmesi gerekmektedir. Bu aşamalar: 
1. Çay bahçesi kurulumu ve çay hasadı öncesi hazırlık aşaması

- Bahçe kurulum hazırlığı

- $\quad$ Fide ekimi (yerinde ekim veya fide ekim)

- Yabani ot ile mücadele

- Gübreleme

2. Çay Hasadı aşaması

- Çay kesme

3. Hasat yapılan yaş çayın muhafazası ve taşınması

- Kesilen çayın taşınması

- Kesilen çayların, yaş çay alım yerlerine ulaştırılması

4. Hasat yapılmış yaş çayın, çay üreticisi firmalara satılması

- Çay alım yerlerinde araç yükleme, boşaltma

- Yaş çay tartım ve satım işleri

5. Son sürgün çay hasadı sonrası bakım işlemleri

- Bahçe temizliği

- Dipten kesme

şeklinde sınıflandırılabilir.

İş sağlığı ve güvenliği açısından çay tarımında çalışanların karşılaşabilecekleri temel tehlike kaynaklarını balık kılçığı diyagramı yöntemi kullanarak ifade edilebilir. Bu yöntem, belirli bir sorunun veya durumun olası nedenlerini belirlemek için kullanılmaktadır (Eraydın ve ark., 2019). Balık kılçı̆̆ı diyagramındaki kategoriler genel olarak Çevre, İnsan, Yöntem, Makineler, Önlemler, Malzemeler ve ölçümler olarak sınıflandırılabilir (İnci, 2016).

Çay toplama faaliyetlerini, yukarıda belirtilen aşamaları da göz önünde bulundurarak balık kılçı̆̆ı diyagramı yöntemi ile ele alınırsa (Şekil-2 ) farklı etkenlerin iş sağlığı ve güvenliği adına olumsuz durumların yaşanmasına sebep olabileceği görülmektedir. 


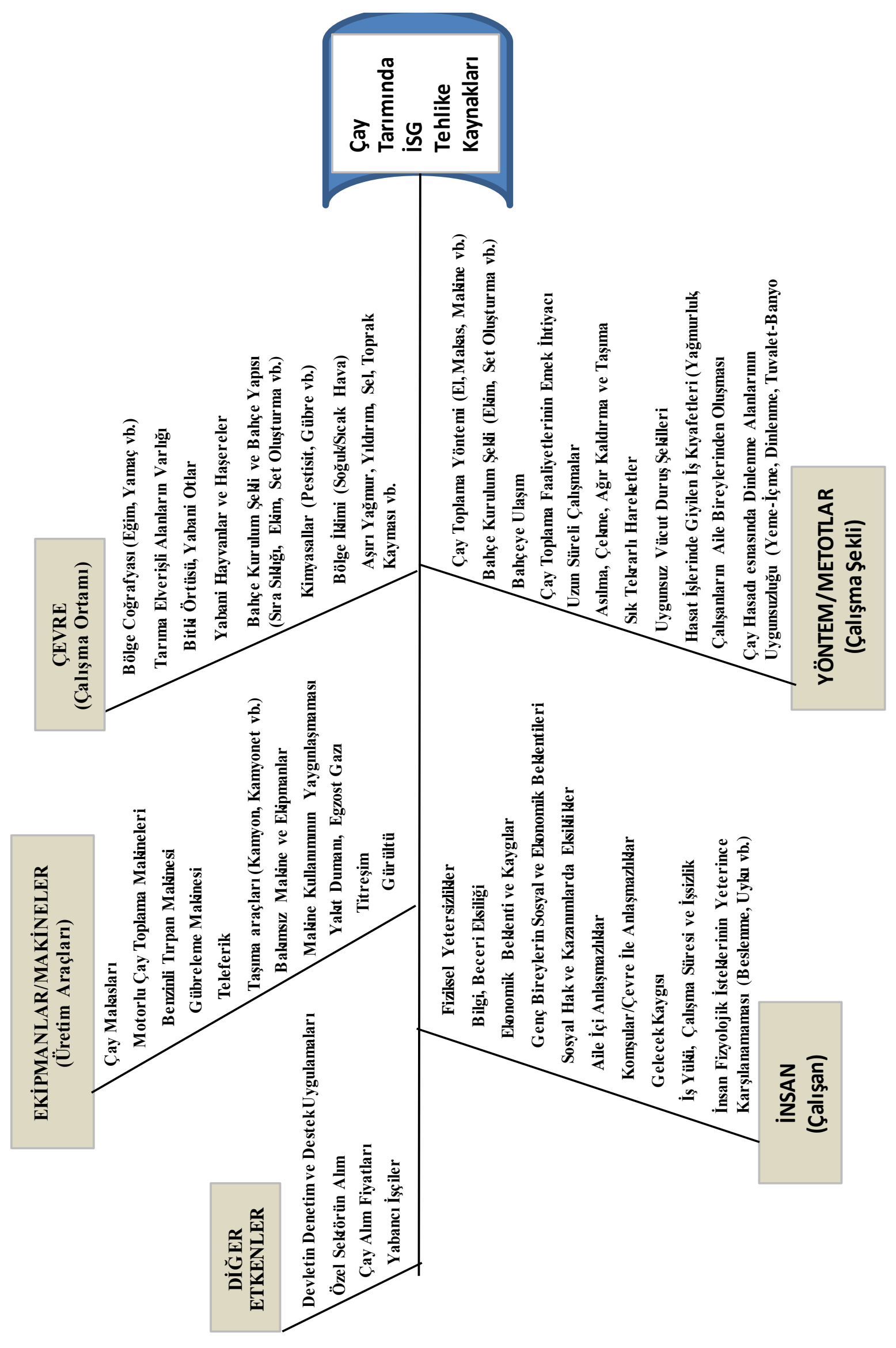




\section{1. Çay Bahçesinin Kurulumu ve Çay Hasadı Öncesi Hazırlık Aşamaları}

Çay tarımı, yıl genelinde aktif çalışma gerektiren faaliyetleri içerir. Tohumun ekimi veya çay fidanının yetiştirilip yerine dikilmesi, çay toplama sezonu öncesi bahçe temizliği ve gübreleme, son sürgün çay hasadı sonunda budama işlemi ve bahçelerin temizlenmesi gibi uzun vadeli çalışmayı içerir (Doğanay, 2011). Çay hasadı öncesi hazırlık aşamaları; bahçe ve çevre bakımı, yabani ot temizleme ve gübreleme olarak sıralanabilir.

Çay bahçelerinin uygun kurulumu, hasat ve taşıma işlemleri için önem arz etmektedir. Bölgenin coğrafi özellikleri nedeniyle tarıma elverişli alanların az olması, dik yamaçlar gibi etkenlerle birlikte, bahçe kurulumunda yeterli deneyim ve bilgiye sahip olunmaması, denetim eksikliği ve planlama yapılamaması, sık dikim, meyil uygulamasının doğru yapılmaması, ulaşım için çay sıraları arasında yeterli alanın bırakılmamış olması gibi hususlar ön plana çıkmaktadır (Çaymer, 2018; Kansız ve ark., 2008).

Çay bahçesi kurulumunda geleneksel yöntemde, çay tohumları açılan gözelere çoklu halde konularak gerçekleştirilmektedir. Günümüzde ise bahçe kurulum ve düzenlemeleri, çay tohumlarından yapılan hazır fidelerin çay bahçelerine dikilmesi şeklinde yapılmaktadır.

Çay fidesi imalatı da yoğun bir işçilik isteyen faaliyettir. Çay hasadı sezonu sonunda çay tohumları toplanır, özel poşetlerde toprağa ekilir ve büyütülür (Şekil-3). Bu süre zarfında da bakımı ve sulaması gibi uygulamalarda yapılmak zorundadır. Bu çalışma; uygunsuz vücut duruşlarına, sık tekrarlı hareketlere, statik duruşlara, aşırı güç uygulamaya, uzun süre ayakta durma veya oturma gibi ergonomik açıdan uygun olmayan çalışma koşullarının ortaya çıkmasına sebep olmaktadır (Aksüt ve ark., 2020).
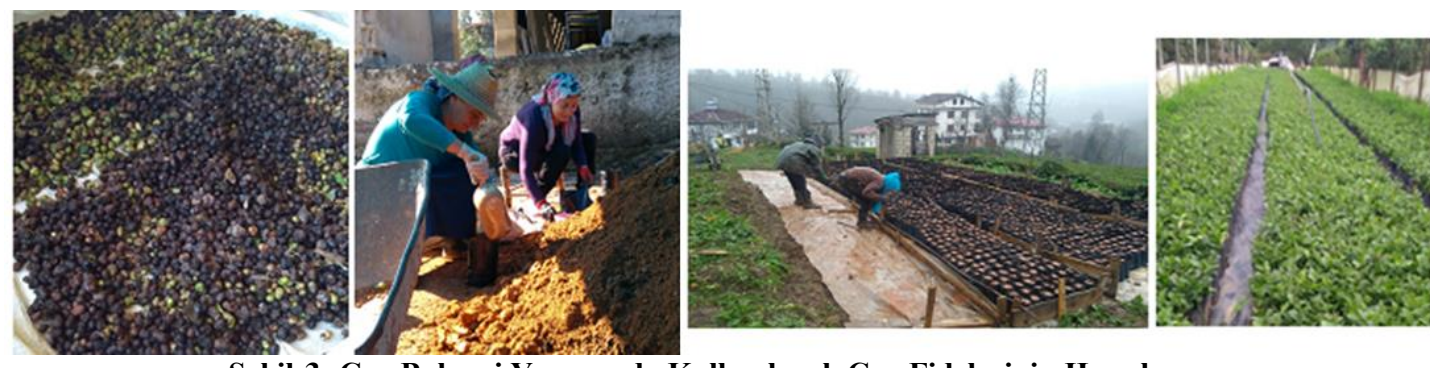

Şekil-3: Çay Bahçesi Yapımında Kullanılacak Çay Fidelerinin Hazırlanışı

Çay bahçelerinde bakım önemli bir sorundur. Çünkü iklimin etkisiyle bahçe içerisinde yabani otlar kolaylıkla büyümekte ve bahçeyi sarmaktadır. Budama işlemi yapılmış alanlarda bu yayılma daha fazla görülmektedir (Şekil-4). Çay bahçelerinde yabani ot temizliği her üç çay hasadı döneminin başında yapılmaktadır.

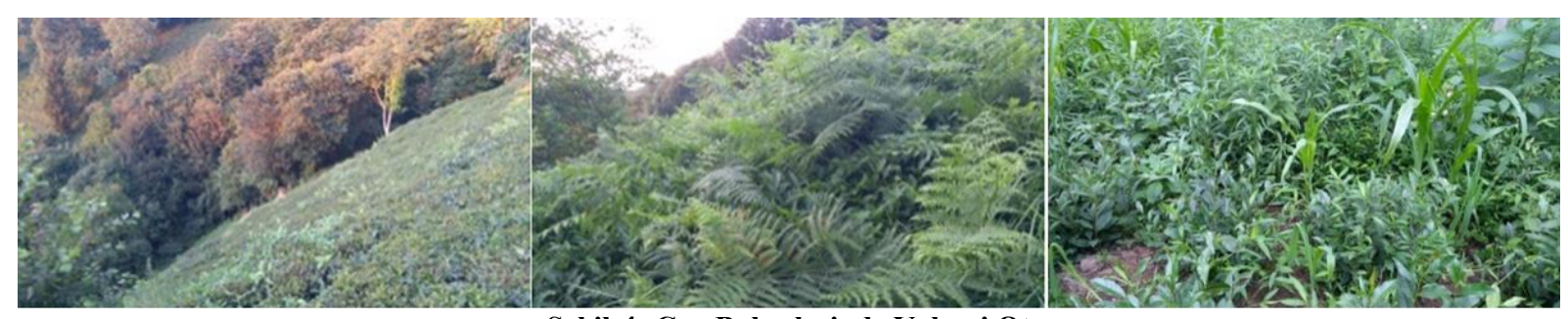

Şekil-4: Çay Bahçelerinde Yabani Ot

Sadece yabani ot olarak bakılmamalı, pek çok çeşidi olan bu bitkilerin içerisinde diken, 1sırgan gibi çeşitlerde yer almaktadır. Gerek çay bahçesi içerisinde gerekse çevresinde ortaya çıkan bu otların temizlenmesi, arazi yapısı ve iklim de göz önünde bulundurulduğunda yoğun bir işçilik ihtiyacı doğurmaktadır. Çoğu zaman yere eğilerek ergonomik olmayan şekillerde sürdürülen bu faaliyette, uygunsuz duruşlar ve uzun süre çalışma sonucu omurilik rahatsılıkları, ellere ve cilde temas sonucu alerji ve yaralanmalar ve ayrıca tehlikeli yabani hayvanlarla (yılan, yabani arı, eşek arısı, kene vb.) temas sonucu yaralanmalar gibi olumsuz sonuçlar ortaya çıkabilmektedir.

Yabani otlarla mücadelede kimyasal ilaç kullanımı uygun görülmemektedir. Hatta ÇAYKUR tarafından kimyasal ilaç kullanan üreticilerin çaylarının alınmayacağı yönünde duyurularda yapılmıştır (Milliyet, 2014). Kimyasal ilaç kullanımı hem üretici hem de üretilen çay açısından tehlikeli durumlara sebep olabileceği belirtilmektedir.

Gübreleme işleminde kimyasal gübre, hayvan gübresi ve çay işletmelerinde üretim sonucu oluşan çay atıklarıda kullanılmaktadır. Beklemiş hayvan gübresi ve işlenmiş çay atıkları sepet veya çuvallar yardımıyla çay bahçesine 
getirilir ve çay diplerine serilir. Kimyasal gübre çuvalları imkân varsa araçlarla eğer yoksa sirtta veya sepetle taşınarak çaylığa getirilmektedir. Kucak diye tabir edilen bez önlüklere parça parça doldurulan gübre, el ile çaylığa serpilmektedir. Bu işlem esnasında çay yapraklarının üzerinde kalan gübreler uzun bir değnek yardımıyla çay öbeğine vurularak aşağı düşmesi sağlanır (Şekil- 5). Bu vurma işlemi esnasında çalışana gübre gelmesi, ilave güç gerektiren bir işlemin doğması ve vurma sonucu çay bitkisinin zarar görmesine sebep olmaktadır.

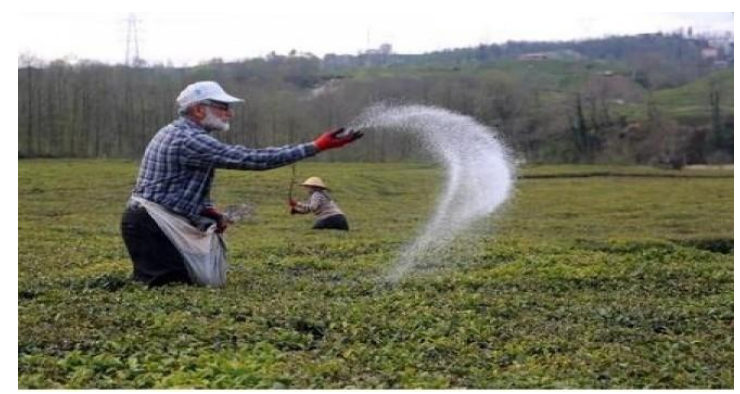

Şekil-5: Elle Gübreleme (http://www.kalkanderehaber.com/yoresel/cay-bahcelerinde-gubreleme-zamani/4727)

Elle gübreleme yerine, sırtta taşınabilen, otomatik gübreleme makinesi kullanılması (Şekil-6 ) önerilmektedir (Önal, 2009).

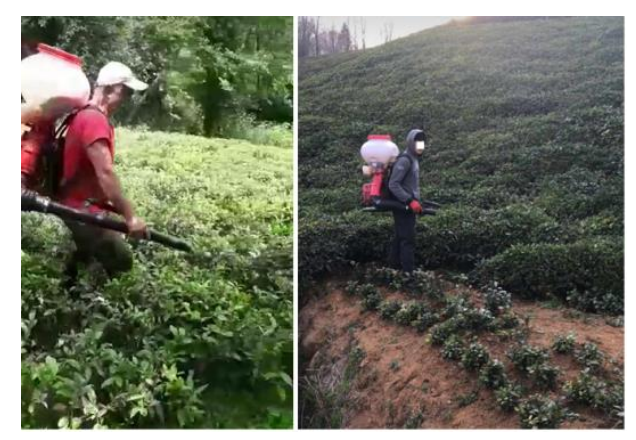

Şekil-6: Gübreleme Makinesi Kullanmı

Gübreleme faaliyetlerinde taşıma ve serme işlemlerinde, ergonomik olmayan çalışma koşullarının oluşması, ağır yük, uzun süreli ve tekrarlı işlerin fazla olması, fazla güç sarf edilmesi ve ayrıca kimyasal ile temas edilmesi gibi tehlikeli durumların ortaya çıkmaktadır. Kullanılan gübreleme makinesi ise gürültü, titreşim, egzost gazı ve ağır yük gibi tehlikeli durumları ihtiva etmektedir.

Çay bahçesi kurulumu ve tarımı ile ilgili iyi uygulama örnekleri Japonya (Chairman, 2005), Endonezya ve Çin gibi ülkelerde gözlemlenebilmektedir (Şekil-7-8-9).

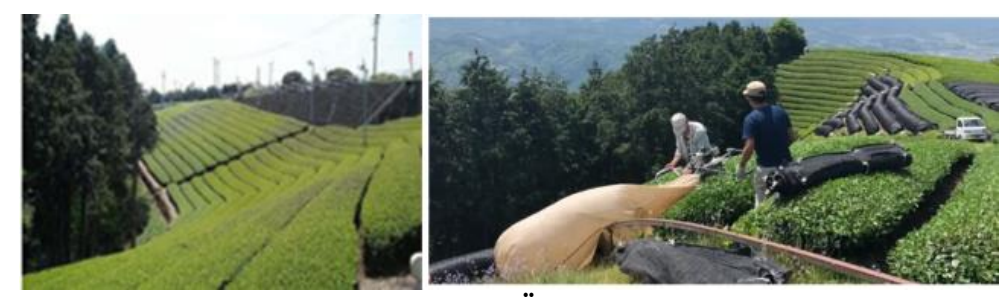

Şekil-7: Japonya'da Örnek Çay Bahçesi

(https://melhadtea.com/blog/japanese-tea-farm)

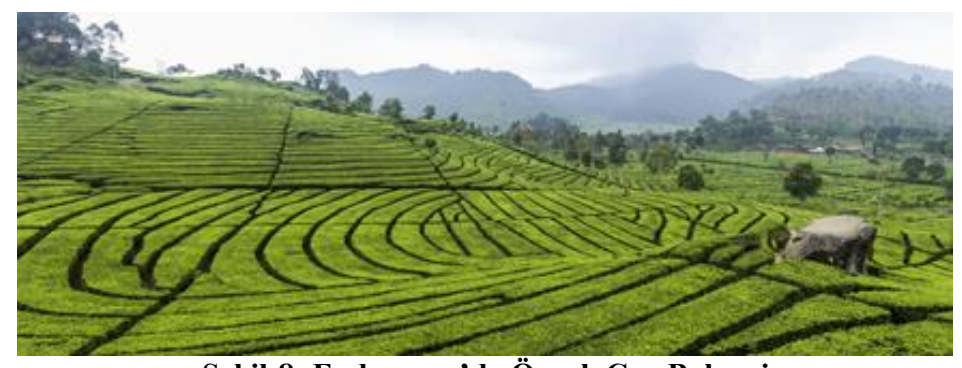

Şekil-8: Endonezya'da Örnek Çay Bahçesi

(https://upload.wikimedia.org/wikipedia/commons/c/cc/Tea_plantation_in_Ciwidey\%2C_Bandung_2014-08-21.jpg) 

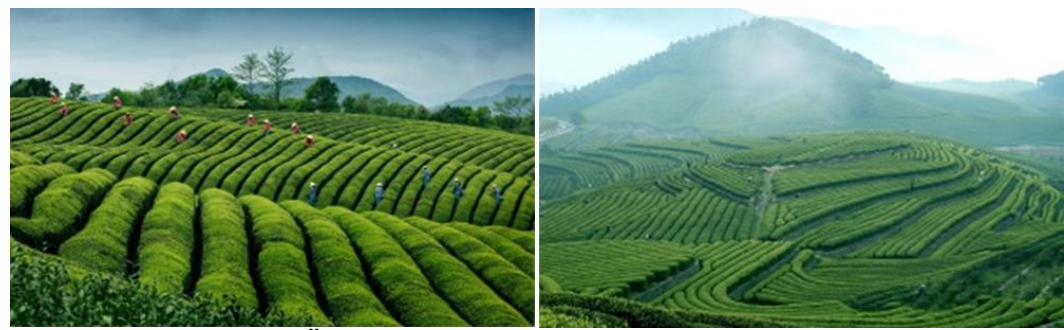

Şekil-9: Çin'de Örnek Çay Bahçesi (http://biriz.biz/cay/china.htm)

\section{2. Çay Hasadı}

Çay toplama işleminde esas nokta taze sürgün kısmının alınmasıdır. Çay hasadı ilk zamanlar elle yapılmaktaydı. Çayın uç kısmından 2 veya 2,5 yaprak şeklinde avuç içine alınıp kırılması (DPT, 1977) ile gerçekleştiriliyordu (Şekil-10). Bu sayede taze kısım alınmakta, sürgün kısmı zarar görmemekte ve kaliteli ürün elde edilmekteydi. Ancak bu yöntemde çay toplama sürecinin uzun olması, yoğun bir işçilik içermesi, ezilen çay filizinden akan sıvının baş ve işaret parmağında cilde teması nedeniyle rahatsızlığa ve tırnakla koparılan filizin tırnak diplerinde yaralanmalara sebep olması çalışanlar açısından tehlikeli durumlar olarak nitelendirilebilir.

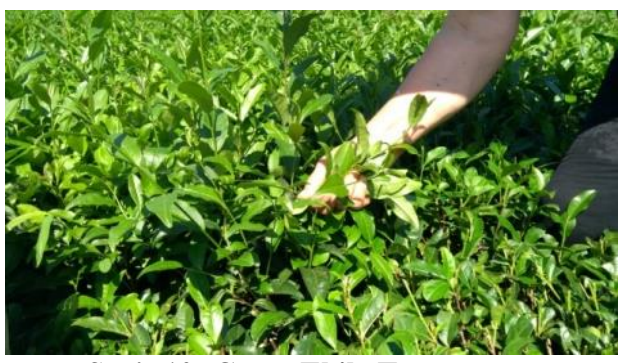

Şekil-10: Çayın El ile Toplanması

Elle toplama işlemlerini takip eden dönemlerde "Çay Orağı" diye tabir edilen, yörede yetişen ağaçlardan (özellikle Komar Ağacı diye adlandırılan Orman Gülü Ağacı) elde edilen dalların iç kısmını incelterek keskinleştirdiği bir alet yapılmış ve kullanılmıştır. Bu sayede el, parmak ve tırnakta meydana gelen rahatsızlıklar bir nebze giderilebilmiştir (Şekil-11).

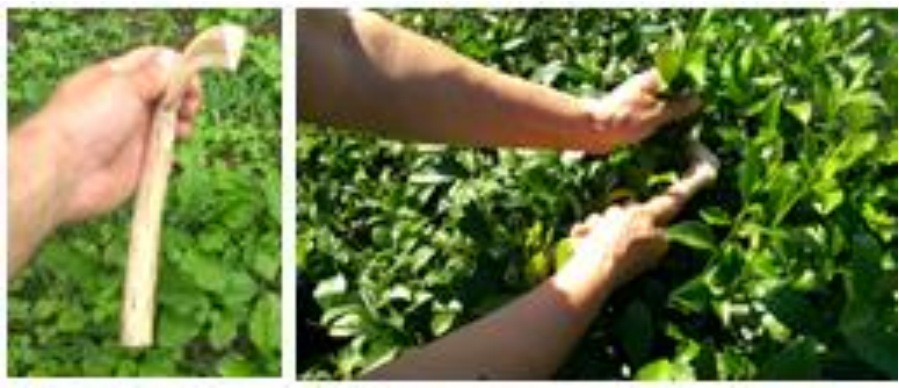

Şekil-11: Çay Orağı ve Kullanımı

Günümüzde çay toplama işleri çay makası ile gerçekleştirilmektedir (Bülbül ve Aydın, 2020). Çay makası iki adet keskin ağızlı, arkasına küçük bir toplama torbası olan bir iş ekipmanı olarak tanımlanabilir (Şekil-12).

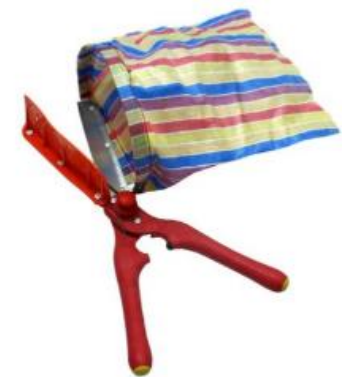

Şekil-12: Çay Toplama Makas (http://biriz.biz/cay/turkcay.htm) 
Keskin iki ağzının olması, kesme işleminde çalışanın dökülen çayları eliyle makasın torbasına doğru toplayıp bastırması, çaylık içerisinde yürürken ağzının açık şekilde veya vücuda dönük şekilde tutulması, makası üreticilerin birbirine atması gibi tehlikeler, yaralanmalara, kesiklerin oluşmasına neden olabilmektedir. Bu makasla çalışma sırasında ayarının düzgün yapılmaması, tutma kolunun ya çok ucundan ya da dip tarafindan tutulması el-kolda ağrılara, fazla güç sarf etmeye ve yorgunluğa sebep olabilmektedir.

Çay makası dâhil pek çok yeni çay kesme makinesi hasat faaliyetlerinde kullanılmaya başlamıştır (Şekil-13). Bu makinelerin benzinli veya akülü motoru olanlar, elde tutulan veya sırtta motor k1smı yer alan ask1lı sistemlileri de mevcuttur.
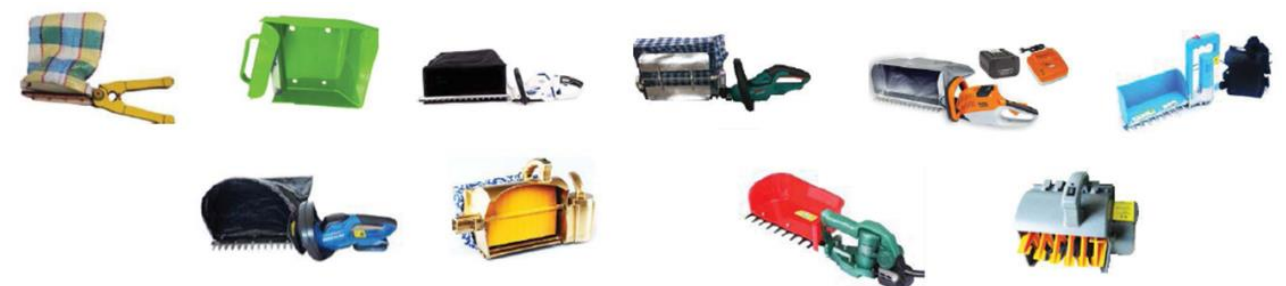

Şekil-13: Çay Hasadında Kullanılan Bazı Ekipmanlar

(Çay Hasadı, Recep Tayyip Erdoğan Üniversitesi, 2020)

Bu makinelerden yaygın olanı, hem benzinli hem de akülü modeli bulunan ve elle tutularak kesme işlemi yapılan çay kesme motordur (Şekil-14).

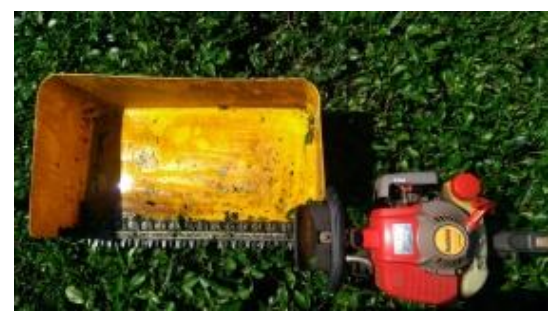

Şekil-14: Benzinli Çay Kesme Motoru

Bu tip kesme makinelerinde kesilen çay haznede toplanır ve üretici çayı peşinde sürüklediği çay sergisine yana dönüşler yapıp atarak boşaltır (Şekil-15).
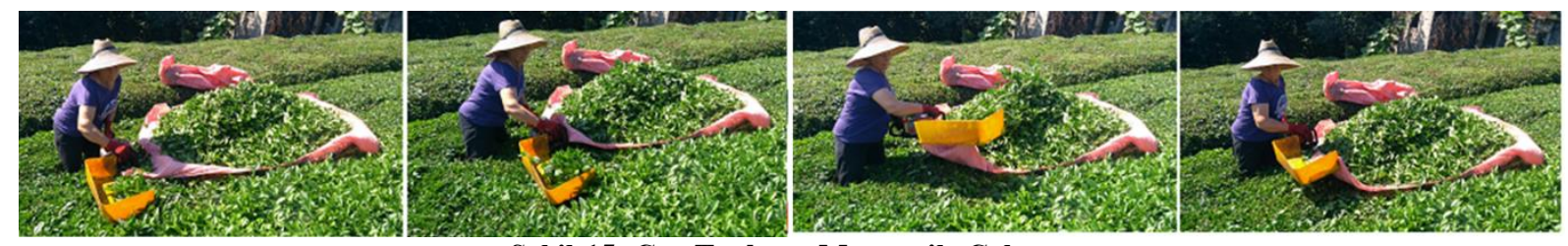

Şekil-15: Çay Toplama Motoru ile Çalışma

$\mathrm{Bu}$ makinelerde hareketli kesici ağız çalışanlar açısından önemli bir tehlike kaynağıdır. Ayrıca başka bir sorun da ağırlığıdır. Çalışanın elle tutması sonucu ekstra yük olmaktadır. Çalışma süresi, çaylıkların $60-70 \mathrm{~cm}$ yüksekliği nedeniyle sürekli eğik şekilde çalışma ve vücuda binen ekstra yük, zorlu çalışma koşullarını oluşturmaktadır. Bu çalışma şeklinde çalışma süresi, iklim etkisi, sık tekrarlı çalışmalar, eğik durma, uzanma erişme ve vücuda yana döndürme gibi zorlayıcı çalışma duruşları; makine ağırlığg, egzoz gazı, gürültü ve titreşim gibi tehlikeli durumlar ortaya çıkmaktadır.

Ayrıca kullanılan makine çayın derinden kesilmesine, sert ve dallı kısımlarında toplanan çaya karışmasına sebep olabilmekte, buda çay kalitesi üzerinde etki edebilmektedir. ÇAYKUR tarafindan yapılan duyuruda benzinli çay toplama makinelerinin çıkardığı egzoz gazı nedeniyle çayda kalıntı oluşabileceği ve bu yüzden çayın kalitesinin düşebileceği belirtilerek bu tip makinelerin kullanımını yasaklamıştır (NTV, 2020). Hem bu hem de benzinliye göre daha hafif, küçük olan akülü tip kesme makineleri tercih edilip kullanılmaktadır.

Hasat işleminde daha önce belirtilen modern bahçelerin avantajı bulunmaktadır. Bu avantajlar; toplama kolaylığı, mekanizasyon imkânı ve ulaşım imkânlarının daha fazla yaygınlaşması şeklinde sıralanabilir (Şekil16-17). 


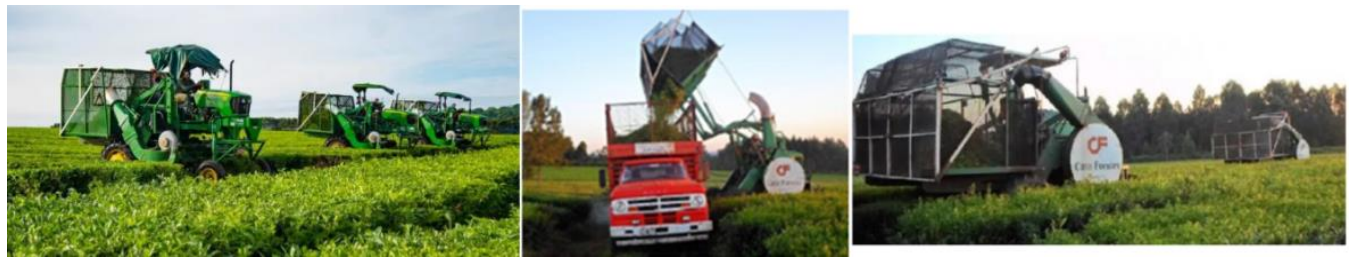

Şekil-16: Arjantin'de Modern Hasat (https://www.finlays.net/about-us)

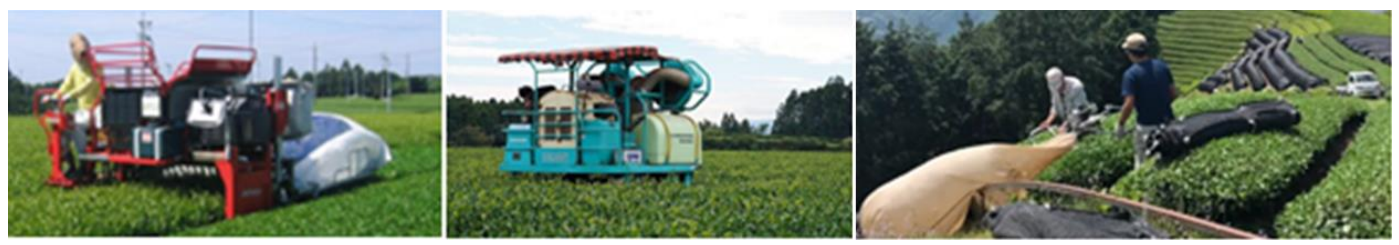

Şekil-17: Japonya'da Modern Çay Hasadı (https://www.instagram.com/justteayourself/)

Ülkemizde, çay tarımı yapılan arazilerin yapısının eğimli ve dik yamaçlar olması, evlerin dağınık halde yerleşimi ve çoğunlukla bahçelerin çay tarımı yapan üreticilerin evlerine uzak olması gibi etkenler nedeniyle çalışma saatleri normal sürelerden oldukça farklıdır.

Çay bahçelerinin uzak olması nedeniyle üreticiler çay bahçelerine eşyalarını koymak, dinlenmek ve yemeklerini yiyebilmek için ufak kulübeler yapmaktadır (Şekil-18a-18b ). Bu kulübeler hava koşullarına göre sığınak olarak da kullanılmaktadır. Ancak uzun süre boş kalan bu kulübeler yılan, fare, arı, örümcek gibi tehlikeli olabilecek hayvanların barınağına dönüşebilmektedir. Kullanılmadan önce ve çay hasadı zamanında her gün kontrol edilmesi gerekmektedir.

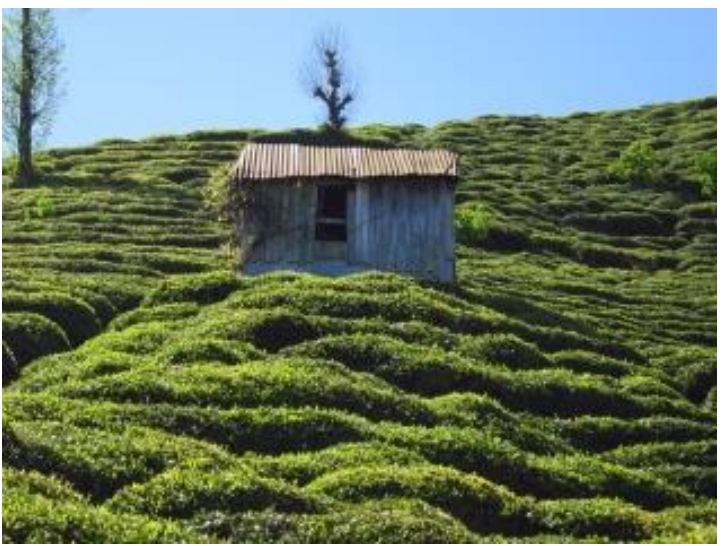

Şekil-18a: Çay Bahçesi Kulübesi (https://pixabay.com/tr/photos/cay-tarlasıkulübe-rize-countrside-1785803/)

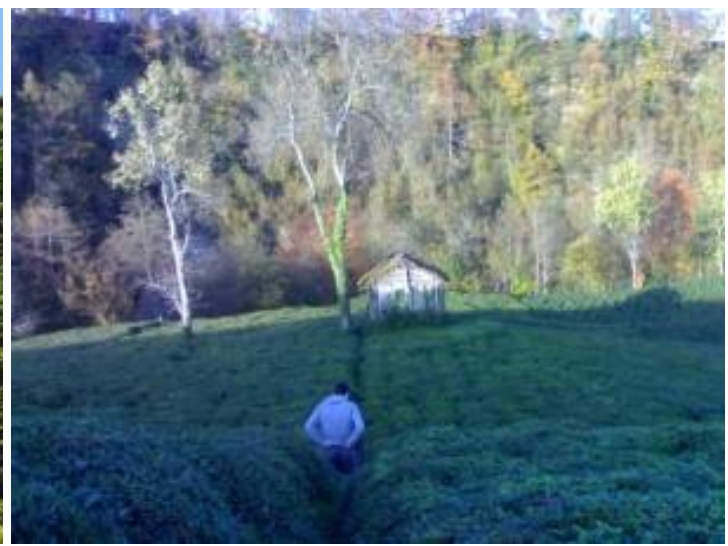

Şekil-18b: Çay Bahçesi Kulübesi

İklim (sıcaklık, yağmur, nem vb.), bahçeye ulaşım, üreticinin çayı hangi firmaya vereceği (devlet veya özel sektör) çalışma süresi ve şeklini de etkilemektedir. Bunun sonucunda uzun süreli ve tekrarlı çalışmalar, yoğun bir çalışma süreci, iklimin insan vücuduna etkisi, ergonomik olmayan uygunsuz çalışma şekilleri üreticiler açısından tehlikeleri ihtiva etmektedir (Şekil-19). 


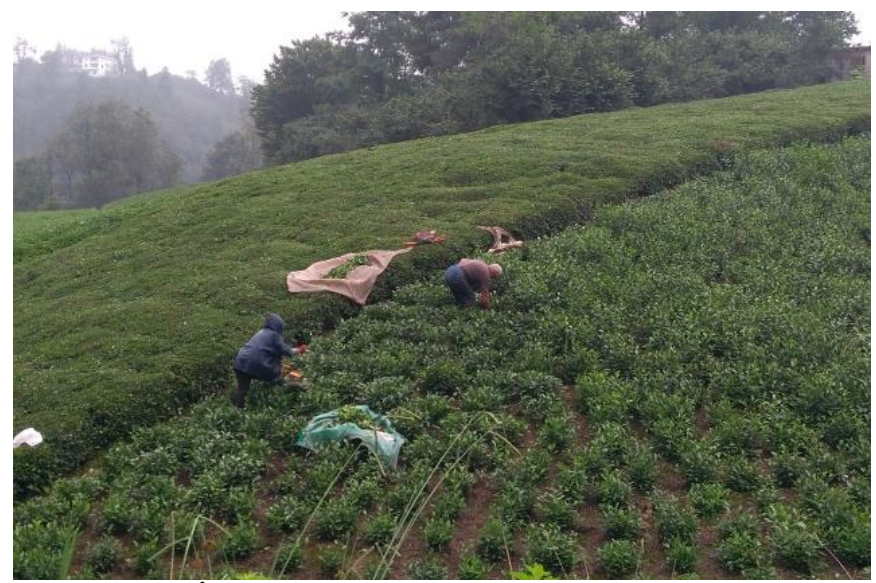

Şekil-19: Dipten Kesme İşlemi Sonrası Yeni Hasadı Yapılan Çay Bahçesinde Çalışma

İklim etkisine göre çay bahçesinde giysi seçimi yapılmaktadır. Güneşli günler için hasır örgü şapka ve normal şapka, kısa kollu elbiseler ve ayakkabı (kara lastik, spor ayakkabı vb.) kullanılabilmekte, yağmurlu günlerde ise yağmurluk ve çizme kullanılmaktadır (Şekil-20).
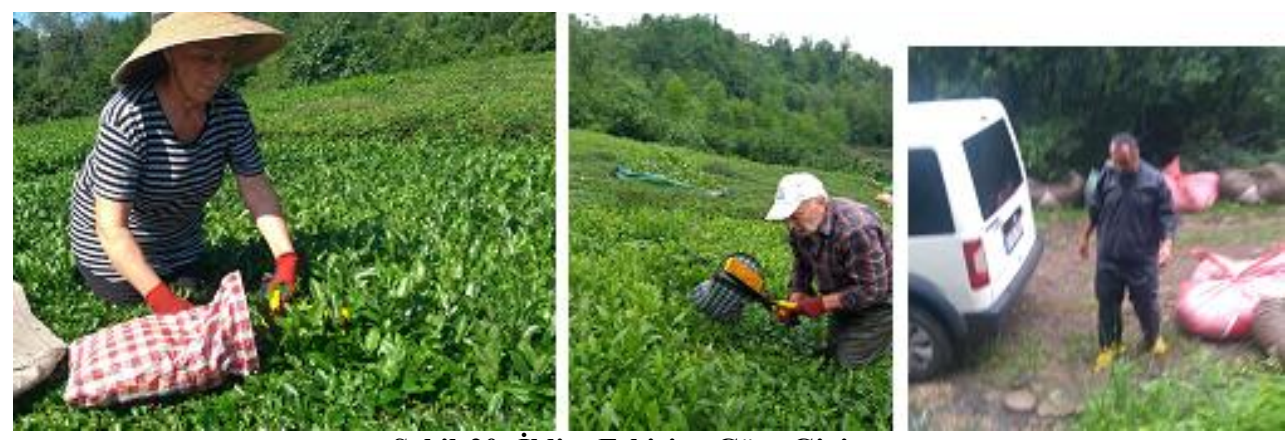

Şekil-20: İklim Etkisine Göre Giyinme

Sıcak günlerde güneş çarpması, aşırı yorgunluk çay toplama işinin yapamama gibi sorunlar ortaya çıkmaktadır. Yağmurlu günlerde ise ilave giysi ile çalışmak daha fazla güç sarf etmeye, giyilmemesi halinde üreticinin çalışma süresince yağmura maruz kalması ve hastalıklara sebep olabilmektedir. Yağışlar ayrıca yıldırım tehlikesine, sel ve heyelan gibi üreticiler açısından tehlikeler sebep olabilecek durumların ortaya çıkmasına neden olabilmektedir (Şekil-21).

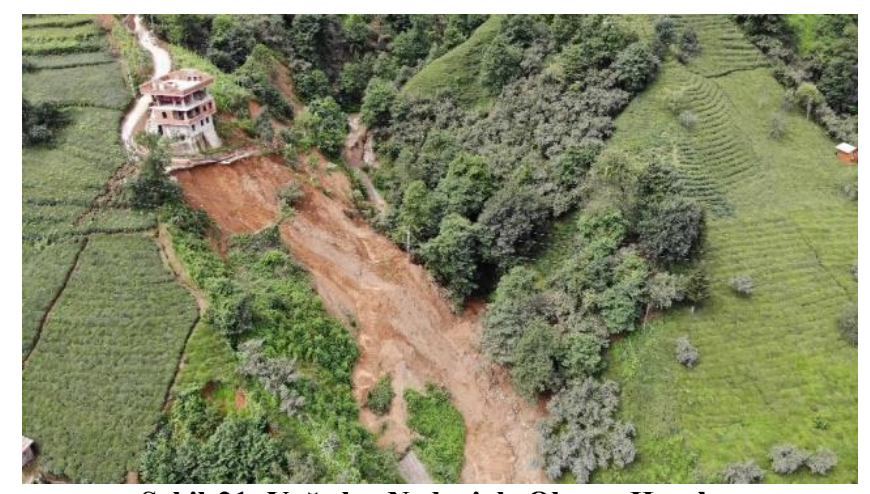

Şekil-21: Yağışlar Nedeniyle Oluşan Heyelan

(https://www.sabah.com.tr/trabzon/2020/08/16/trabzonun-of-ve-hayrat-ilcelerindeki-selden-en-fazla-zarari-caybahceleri-gordu)

Çay bahçelerinde yılan tehlikesine karşı çizme ile çalışma daha fazla yapılmaktadır. Ancak sıcak havada ayağın sürekli çizme içerisinde kalması ayak tabanında rahatsızlıklara, parmak duruş şekillerinde bozulmalara sebep olmaktadır. Yağışlı günlerde ise çizme içlerinin su ile dolması, ayağın sürekli suyun içinde kalması gibi sorunlarla karşılaşılmaktadır. Ayrıca çizme veya ayakkabı içine dolan küçük dallar, çay tohumu gibi maddeler çalışanın duruşunu rahatsızlaştırmakta, çalışmayı zorlaştırmaktadır. Çay bahçelerinin sık bir şekilde oluşturulması nedeniyle giyilen pantolonun kalın kumaşlı olması bacakların çay dalları tarafından çizilmesinin önlenmesi adına önemlidir. Kalın eski dallar bacaklarda daha ciddi yaralanmalara sebep olabilmektedir. Ayrıca 
çay toplama işlemleri esnasında eldiven kullanımı; elle toplama işleminde filizin ve çay öz suyunun parmağa zarar vermesini önlerken, çay makası veya makine ile kesme işlemlerinde, kesme sonucu yüzeyde ortaya çıkacak ince dalların ele zarar vermesini engeller. Ayrıca eldiven, çay makasının veya makinenin tutma kolunu daha rahat kavranmasını, avuç içlerinin nasırlaşmasını bir ölçüde engellemektedir. Kesme sırasında bileklerin sürekli hareketli olması ve yük binmesi nedeniyle zorlanmaya maruz kalmakta, buna karşın çalışanın bileği desteklemesi adına bileği sarması sıklıkla yapılan bir harekettir.

Çay üretimi esnasındaki diğer bir sorun hijyen sorunudur. Üretim alanlarının evlerden uzak olması, tuvalet ihtiyacının uygun şekilde yapılamaması veya uzun süre engellenmesi, yemek öncesi temizlik işinin uygun şekilde yerine getirilememesi, uzun süre kirli giysilerle kalınması ve duş ihtiyacının geç saatlerde yerine getirilmesi bu sorunların öne çıkanlarındandır.

\subsection{Hasadı Yapılan Ürünün Muhafazası ve Taşınması}

Hasat yapılacak çayın hangi çay firmasına verileceği ve çayın verileceği firmanın çay alım yerinin dolu olup olmaması çay toplama süresini etkilemektedir. Çaylar özel sektöre verilecekse ve çay alım yerinin uygun olması durumunda akşama kadar çay toplanır, ya kesilmiş çaylar parça parça çay alım yerine taşınır verilir ya da akşam tek seferde çaylar alım yerine teslim edilir. ÇAYKUR'a ait yerlerde, üreticinin vermesi gereken çayın miktarı, alım günü ve saati belli olduğundan üretici kendini ona göre ayarlamaktadır.

Taşıma işlemlerinde çay sergilerinin bağlanması, kaldırılması, araca yüklenmesi gibi işlemler iki kişi tarafından yapılması gerekmektedir. $\mathrm{Bu}$ işlerin tek başına yapıldı̆̆ı durumlarda; bel, boyun, ayaklar ve omurgayı zorlamakta ve fazla yük binmekte, çalışan aşırı güç sarf etmektedir. Çay taşıma işlerinde; hazırlanan çay sergilerinin ağırlıkları, havanın sıcak veya yağışlı olması, taşıma güzergâhında uygun geçiş aralıklarının olmaması, arazinin meyil durumu, yerin kaygan olması, giyilen ayakkabının da önemli etkenler olduğu kabul edilmeli.

Dalında taze ve ağır olan çay, kesilip toplandığında kurumaya ve suyunu kaybetmeye başlamaktadır. Özellikle sıcak havalarda kesilmiş çayın daha hızlı bir şekilde suyunu kaybettiği, fazla güneş altında kalması halinde yanmaya başlayacağı kesilmiş çayın çay bahçesinden çıkartılıp daha uygun yerlerde (ağaç altları, gölgelik alanlar vb.) saklanmaları zorunluluğunu doğurmaktadır. Yağmurlu havalarda su kaybı olmayacağından kesilmiş çaylar çay bahçesi içerisinde bekletilebilmektedir (Şekil-22).

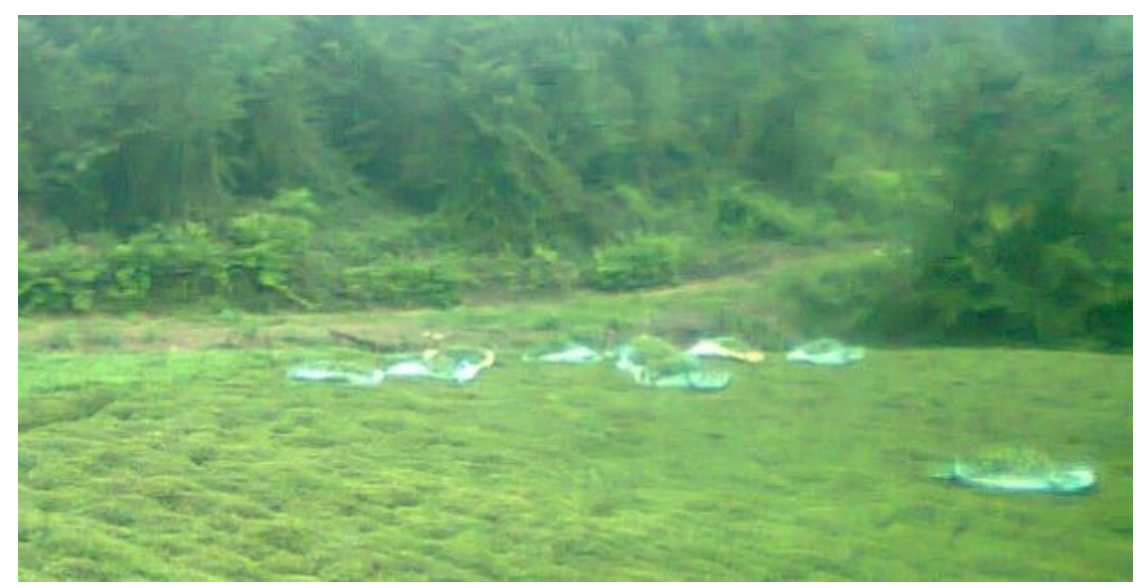

Şekil-22: Çay Bahçesinde Bekleyen Hasadı Yapılmış Çaylar

Çay kesme işlemi yorucu bir iştir. Ancak kesilmiş çayın taşınması daha fazla yormaktadır. Güneşli havalarda çay kesilir, çay sergisi bağlanarak taşıma işlemi hemen yapılır. Taşınan sergiler, çayın, alım yerine getirileceği araçların yakınında uygun gölgelik alanlarda açılarak bekletilir. Bu işlem ilave işçilik gerektirmektedir. Yağışlı havalarda ise çayın erkenden taşınmasına gerek yoktur. Ancak sergi içerisinde bekleyen çayın yağmurla beraber daha ağırlaşacağı, taşımasının daha zor olacağı göz önünde bulundurulur. Bu yüzden taşıma işi belirli aralıklarla yapılarak kesilen çaylar araçların yakınına getirilir (Şekil-23). 


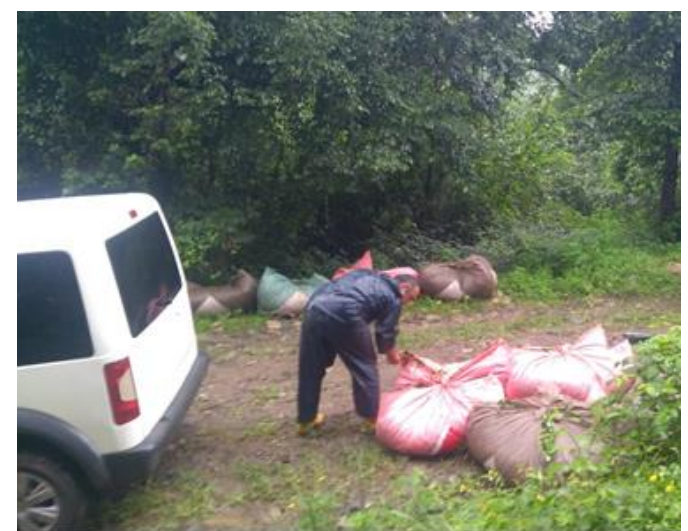

Şekil-28: Çayın yol kenarına getirilmesi

Çay genel itibariyle sırtta taşınır (Şekil-24). Bu ișlemden boyun omuzlar, bel, bacaklar ve omurga etkilenmektedir. Çay sergisinin bağlanması iki kişi tarafından yapılır. Kaldırma işlemi ise değişik şekillerde yapılabilmektedir. Yaygın olarak yapılanı çayı taşıyacak kişinin yere çömelerek çay sergisinin iki ucundan tutması ve ayağa kalkması, diğer çalışanında kalkarken ona yardım etmesi şeklinde gerçekleştirilir. Bir başka yöntemde ise bağlanmış olan çay sergisinin uçlarından iki kişi tutar, sergiyi yana doğru sallayarak ivme kazanan serginin altına biri geçerek omuzuna alır. Bir başka yöntemde çaylık içinde veya eğimli arazide bağlanmış çay sergisini çalışan kendi imkânıyla (sergiyi kucaklar ve boynunun üzerinden sırtına doğru alır veya bağlı sergiyi dikleyerek aşağı kısmına geçer ve yere diz kırarak oturur, yerden güç alarak ayağa kalkar) sırtına alarak taşır.

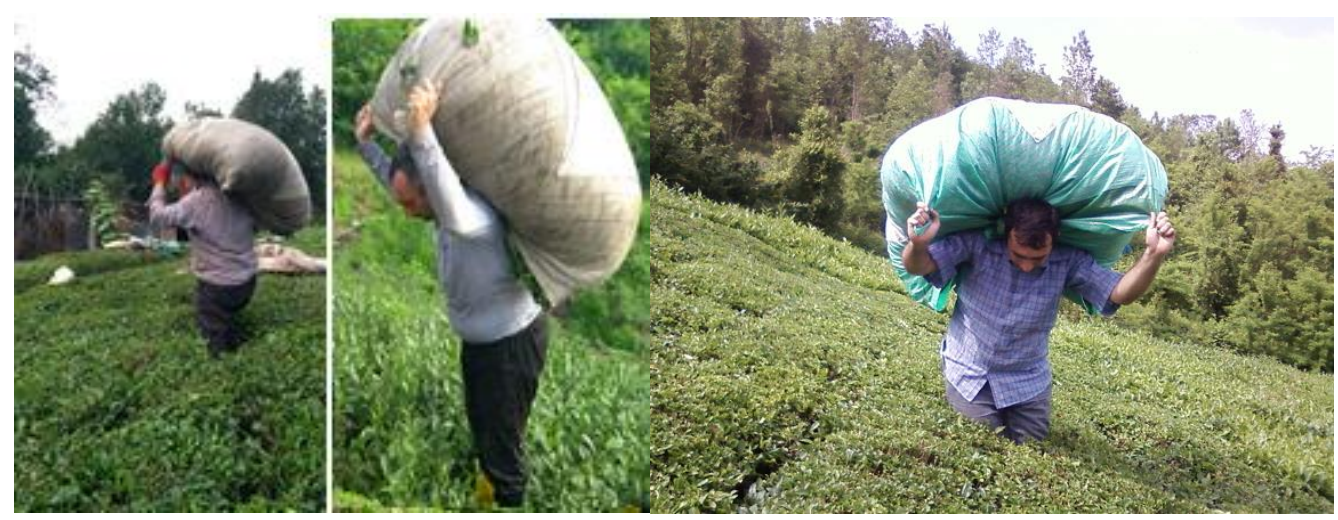

Şekil-24: Omuzda çay taşıma

Bir başka çay toplama ve taşıma işleminde kullanılan ekipman ise yerel ağızda "Hemençe" de denilen, ağaç dalında örme şeklinde veya bezden yapılan sepetlerdir (Şekil 25a-25b). Elle ya da makasla toplama işlemlerinde sırtta da tutulabilen sepet genel olarak çalışanın yanında yerde tutulur. Dolduğu zaman çalışan onu çay sergisine getirerek boşaltır. Askı ipleri ile sırtta daha dengeli bir duruş sağlamakta, eğimli arazilerde kullanımı tercih edilmektedir.

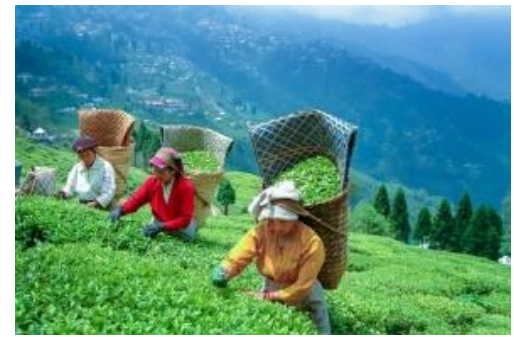

Şekil 25a: Çay toplama ve taşıma sepeti (https://www.mutfakmagazin.com)

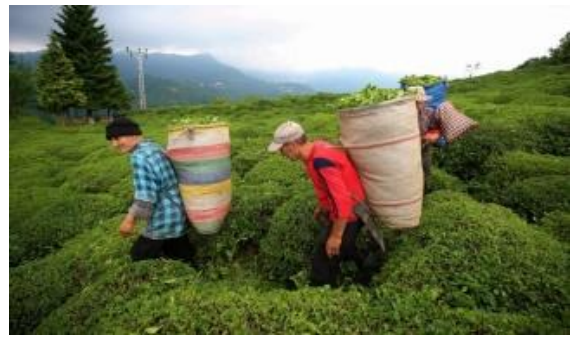

Şekil 25b: Çay toplama ve taşıma sepeti (http://www.madeinturkeydergisi.com)

Taşıma işlemlerinde hava durumu, çay fidelerinin dikim sıklığı, taşıma yapılacak mesafe, gidilecek yolun yapısı, arazi yapısı ve taşınan serginin ağırlığı önem arz etmektedir. Arazi yapısı nedeniyle çoğu çay bahçelerine yol gidememekte ve taşıma işleminin uzun mesafelerde yapılması gerekmektedir. Kayma düşme tehlikesi içeren çamurlu yollardan taşıma yapılması (Şekil-26) zorlu taşıma koşullarındandır. 

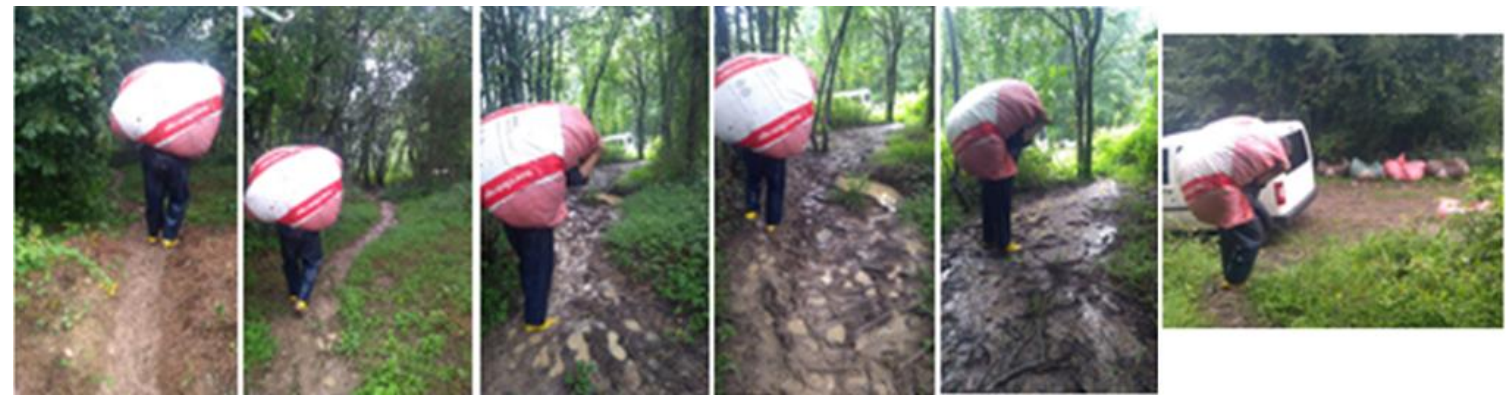

Şekil-26: Çay Taşıma Güzergâhı

Ayrıca bahçe içerisinden, sık dikilmiş çay fidanları arasından yol açarak uzun mesafe gitmek ve üreticinin kendi imkânlarıyla oluşturduğu ahşap geçitlerden geçmek taşıma işlerinin zorluklarındandır (Şekil-27).
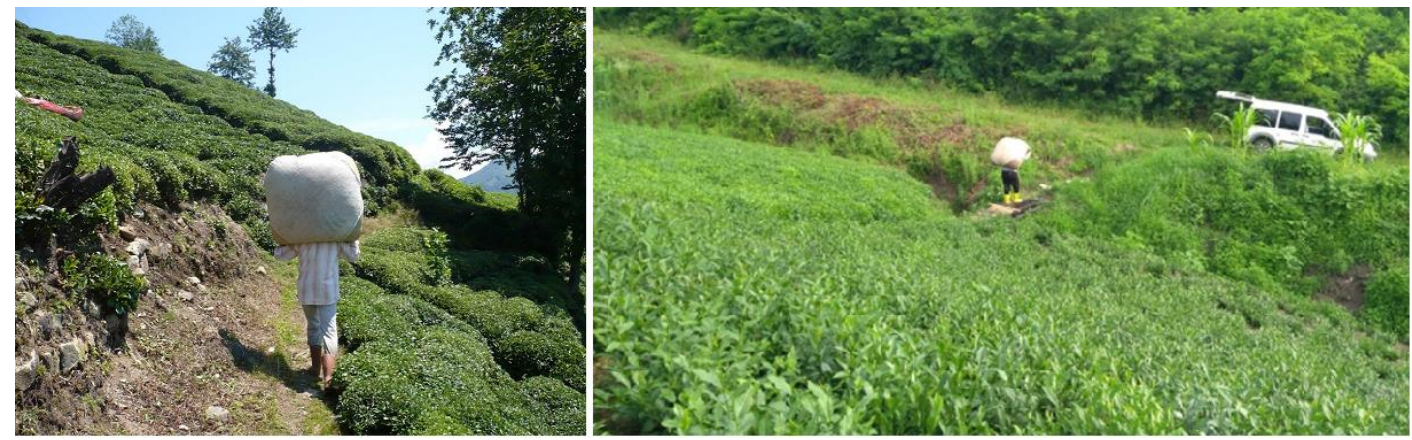

Şekil-27: Uzun Mesafeli Taşımalar (http://rizeazaklihoca.blogspot.com/2008/07/azaklihoca-ky-ay-baheleri-aytoplama_30.html)

Diğer etkili bir taşıma şekli ise, "Varagel" olarak da isimlendirilen, teleferiklerdir. Özellikle eğimli ve dik arazilerde yaygın olarak kullanılmaktadır. Genel olarak çelik teli saracak motorun bulunduğu ve kullanılacağı, çayın indirilebileceği uygun nokta, çay bahçesi içerisinde eğime göre ve teleferik telinin yüksekliğinin korunması adına geçiş noktaları ve çay bahçesinin sonunda uygun alanda seçilen bir nokta belirlenir ve bu güzergahta bir hat oluşturulur. Gergin hale getirilen telin üzerinde, hareket eden makaralara bağlı tablayı çeken bir çelik halattan oluşur (Şekil-28).

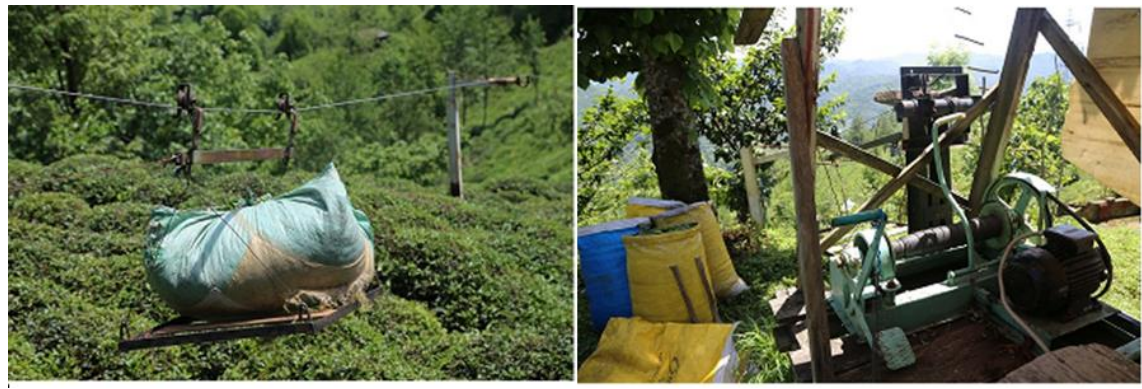

Şekil-28: Teleferik (http://www.mmorize.org/mmo_rize_haber15.htm)

Teleferikler çay sergilerinin taşınması adına oldukça kolaylık sağlamaktadır. Çay sergilerinin iki kişi tarafından teleferik tablasına yerleştirilmesi gerekmektedir. Tek başına yerleştirme işleminin yapılması çok zordur. Teleferik motorunu kullanan ile çay yüklemesini yapanlar birbirlerini göremeyebilir duyamayabilir. Bu da her iki taraf arasında iletişimde kopuklukların yaşanmasına sebep olabilmektedir. Telsiz yada telefonla haberleşme imkanlarının olmaması tehlikelere sebep verebilmektedir. Teleferikle çalışmada yükleme yapıldıktan sonra teleferik teline sert şekilde birkaç kez vurularak kullanıcıya motoru çalıştırması yönünde işaret verilir. Bazen kullanıcı bunu farkedemeyip yükleme esnasında oluşan salınım ve çarpmaları işaret olarak algılayabilmekte ve teleferiği çalıştırmaktadır. Buda yükleme yapan çelışanın yaralanmasına, teleferikle sürüklenmesine sebep olabilmektedir. Yük yukarı çekildiği zaman kullanıcı zamanlamayı iyi yapmalı ve motoru kapatmalıdır. Aksi halde yük tablası son noktaya çarpabilmektedir. Bu çarpma sonucu orada bulunan başka kişiler, motoru kullanan kişi zarar görebilir, yaralanabilir. Bu çarpma sonucu halat kopabilir, makaralar yerinden çıkabilir. Çay taşıma 
amacı ile yapılan bu teleferikler maalesef insanların taşınması içinde kullanılabilmektedir. Halat kopması, teleferik çarpması, teleferikten düşme vb durumlarda çeşitli yaralanma ve ölüm olayları gerçekleşebilmektedir (Bıçakçı, b.t.).

İş makinesi kapsamında değerlendirilmesi gereken bir ekipman olan teleferik maalesef ülkemizde ilkel şekillerde kurulmaktadır. Herhangi bir kurulum planı, kontrol ve denetime tabi tutulamamaktadır.

Dik yamaçlar ve taşıma zorluğu, kesilmiş çayların çift segi ile bağlanması ve yokuş ağağı yuvarlanması şeklinde de taşınabilmektedir. Sıkıca bağlanan çaylar, üreticinin belirlediği alanlardan aşağı doğru yuvarlanır. Varış noktası olarak yola yakın veya taşıma işleminin daha rahat yapılabileceği alanlar seçilebilir. Bu şekilde gerçekleştirilen işlemler; yuvarlanan çay sergilerinin aşağıda bulunanlara çarpması, yoldan geçen yaya yada araçlara çarpması tehlikelerini içermektedir. Ayrıca yuvarlama güzergahında ağaç, çalı vb. yerlere takılması veya durması gereken mesafeden daha uzağa gitmesi ya da diken, 1sırgan otu vb. yabani otların arasına düşmesi gibi ilave güç sarfettirecek, ciltte tahriş ve yaralanmaya sebep olabilecek durumların ortaya çıkması ihtimali söz konusudur.

\subsection{Hasadı Yapılmış Ürünün Çay Fabrikasına Satııması}

Hasadı yapılan ve taşınan ürünler son olarak çay alımı yapan firmaların çay alım ambarlarına getirilir (Şekil-29).
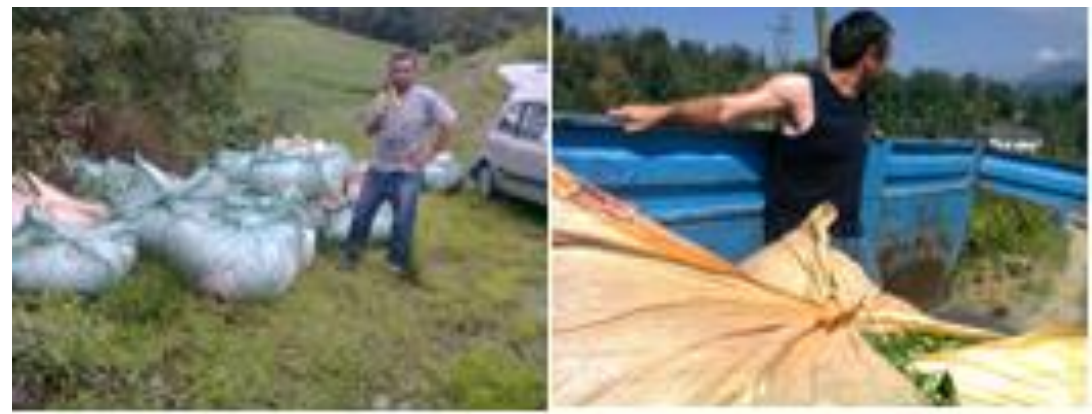

Şekil-29: Çay Hasadı Sonu ve Çayların Taşınması

Kesilmiş yaş çaylar ambarda kantarda tartılır ve çay üreticisinin çay cüzdanına//hesabına işlenir. Çay üreticisi çay alım yerine getirdiği çayı kantara yükler ve tartımdan sonra yere indirir. Çay alım yerinin içerisine sergiyi çekerek boşaltır. Yığın halinde duran çayın yanmaması için dişli küreklerle havalandırılması, yayılması gerekmektedir (Şekil-30). Bu işlemi ya üretici ya da belli ücret karşılığında kürekçi denilen kişiler yapar.
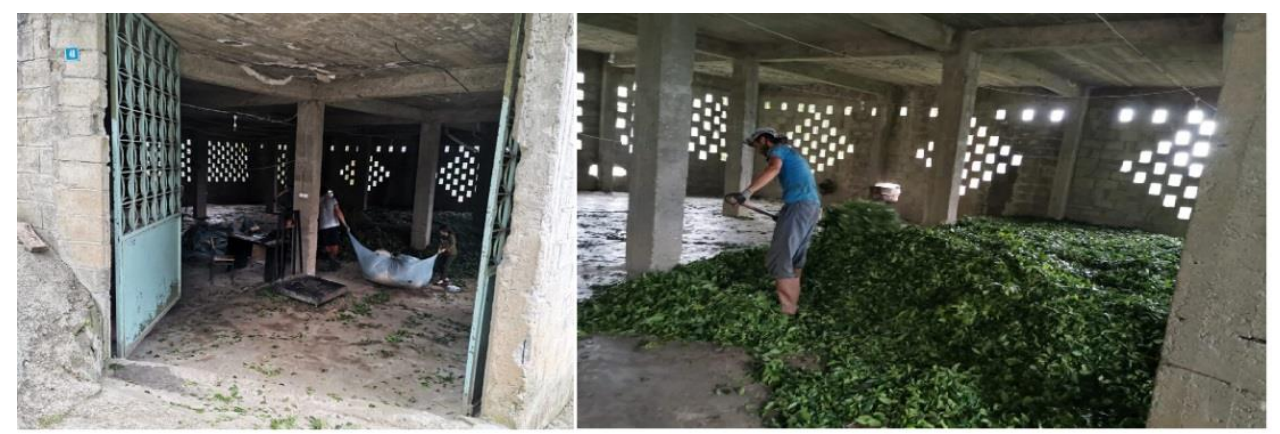

Şekil-30: Yaş Çay Alım Yeri (https://www.nextvery.com/cay-nasil-toplanir-cay-kesme-motoru-nedir-kurt-cayiscileri-gurculerin-yerini-alabilecek-mi/)

Başka bir şekilde ise üretici topladığı çayı taşıma araçlarına yükleyerek direkt fabrikalara getirip satabilmektedir. Ayrıca gezici olarak dolaşan ve çaylıktan çayı peşin paraya alan girişimcilerde mevcuttur.

$\mathrm{Bu}$ aşamada, yükleme boşaltma ve satım işlemlerinde, araç üzerinde yolculuk, ağır yük kaldırma, uygunsuz vücut duruşları (asılma, çekme, fırlatma, kürekleme vb.) ve aşırı efor sarf etme gibi tehlikeler çalışanları beklemektedir. 


\subsection{Son Sürgün Çay Hasadından Sonra Yapılan Bakım İşleri}

Ülkemizde mayıs ayında başlayan çay hasadı ekim ayında tamamlanmaktadır. Bundan sonraki sürede çay bahçesi ve çevresinin bakım ve temizliği yapılır.

Öncelikle çay bahçesindeki yaşlanmış çayların dipten kesilmesi işlemi yapılır. Bundaki amaç hem bahçeyi genç tutup verimi artırmak hem de sonraki sürgün döneminde ÇAYKUR'a çay verebilmektir. Dipten kesme işlemleri ucunda çelikten kesme ağız bulunan, sırta takılan motorlu tırpanla yapılmaktadır (Şekil-31).

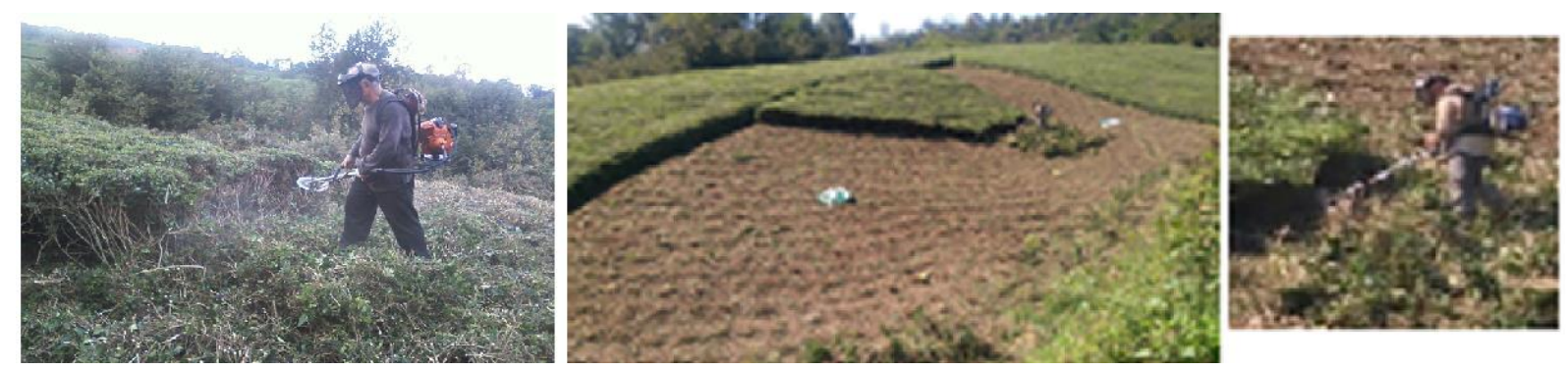

Şekil-31: Çay Bahçesinin Dipten Kesimi

Benzinle çalışan bu tırpanda, çalışan açısından çeşitli tehlikeler mevcuttur. Tek başına çalışan üretici benzini doldurduktan sonra, motoru çalışırımakta ve sonra makineyi sırtına giymektedir. Bu esnada tetiğin takılması metal ağızlı kesme ucunun çalışmasına, yerde sekerek üreticinin üzerine gelmesine sebep olabilmektedir. Kesme işlemi esnasında, kullanııının, kesme ağzının dallara takılarak sekme ihtimaline karşı tırpan kolunu sıkıca tutması, kesme ağzı ile arasındaki mesafeyi ayarlaması ve ağzın devrini düzgün ayarlaması gerekmektedir. Kesme işlemi esnasında çay dallarının firlayıp yüze gelmesi, makinenin gürültüsü ve titreşim kullanıcı açısından da tehlike arz etmektedir. Bu yüzden çalışanın yüz siperliği, kulaklık ve eldiven ile çalışması gerekmektedir.

Bakım işlemleri çay bahçesi dışında da yapılmalı, ulaşım yolları ve etrafının bakımı, çay bahçesi yakınındaki ağaçların budanması ve etraftaki yabani ot, bitki, diken, sarmaşık vb. temizlenmesi de yapılmalıdır (Şekil-32).

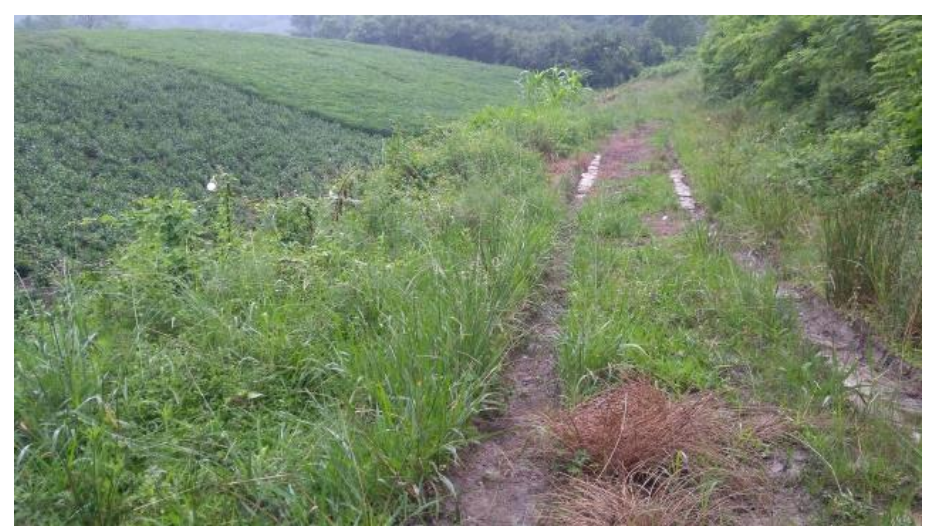

Şekil-32: Çay bahçesi ulaşım yollarının bakım ihtiyacı

\section{6. Çay Hasadında Sosyolojik, Kültürel ve Ekonomik Etkenler}

Günlük hayatta tüketimi hem sosyal hem de kültürel anlamda yer edinmiş olan çay, bölge insanının sosyal hayatına yön veren bir faaliyet haline gelmiştir. Çay hasadı dönemlerinde yöre halkı günlük hayatını bu faaliyetlere göre belirlemektedir.

Çay hasadı bölge halkı için önemli bir gelir kaynağıdır (Alikılıç, 2016). Genel olarak aile halkı tarafından gerçekleştirilen toplama işlemi, eskiden imece usulü ile de yapılabilmekteyken, günümüzde geçici iş̧̧i veya yarıcı usulü toplatma yöntemleriyle de gerçekleştirilmektedir.

Belirli dönemlerdeki hasat faaliyetleri ile getiri kazanılması ve sonraki dönemlerde belirsizliğin olması, elde edilen gelirin ailede kalması ve para yönetiminin aile reisinde olması, gençlerin yeteri kadar pay alamaması, gençler açısından sorun olarak görülmektedir. Eğitim seviyesinin artması ve değişik şehirlerde iş hayatına girilmesi, başka üretim dallarında iş başı yapıldığında sabit ve devamlı bir ücrete, sigorta hakkına ve çalışma düzenine kavuşulması gibi etkenler ekonomik açıdan ön plana çıkmaktadır. Ayrıca üretim sonucu elde edilen gelirin kısa vadeli satışta düşük olması, uzun vadeli satışta ise bir yılı aşan bir sürede elde edilmesi gelirde 
düzensizlik yaşanmasına sebep olmaktadır. Tüm bunlarla birlikte arazi yapısı, çay toplama işinin zorluğu, sahip olunan çay bahçesinin dönümü ve verimi, çay bahçelerinin miras yoluyla paylaşımı, miras sahiplerinin kendi işleriyle uğraşması, üretime katılmaması, çay üretimi için yapılan masraflar (ulaşım, toplama, bakım, gübreleme, satış vb.), üretim esnasındaki uygunsuz kesme / toplama yöntemleri, kesim sonucu ürünü satamama nedeniyle fire oluşması, devletin belirlediği üretim kotası uygulaması, iklim nedeniyle verim düşüklüğü ekonomik olarak etkili diğer unsurlar olarak sayılabilir.

Çay toplama işlerinde yurt dışı kaynaklı işçi çalıştırma yaygın şekilde uygulanmaktadır. Bu işçiler özellikle Gürcistan'dan gelmektedir. Genel olarak çalışmak için erkekler gelmektedir. Kalma, barınma, temizlik, ücret, sosyal yaşantı farkı, dil farkı gibi hususlarda zorluklarla karşılaşabilmektedirler (Engin, 2017). Yerli çalışanlardan ucuza çalışmaları, çay toplama işini topluca daha hızlı bir şekilde çözme düşüncesi gibi nedenlerden dolayı üreticiler tarafindan tercih edilmelerine sebep olmaktadır. Çay toplam sezonu boyunca faaliyet gösteren geçici işçilerin, sezon bitince geri dönmeleri, çay bahçeleri için diğer işlemlerin üretici tarafından yapılmasına sebep olmaktadır. Bu açıdan bakıldığında çay toplama işleminin sürekliliğinin, yani yıl boyu, olmaması asıl iş olarak değerlendirilmemesine sebep olmaktadır. Geçici iş olarak değerlendirilmesi olumsuz bir yansıma olarak kabul edilebilir.

\section{Tartışma}

Doğu Karadeniz Bölgesi’nin önemli bir markası haline dönüşen çay, hem üretim hem de tüketim açısından vazgeçilmezler arasına girmiştir.

Üreticinin desteklenmesi, bilgilendirilmesi önemli bir etken olarak karşımızda çıkmaktadır. Üretim faaliyetlerinin maliyet olarak önemli bir etken olarak ortaya çıkması, üreticinin ekonomik açıdan desteklenmesi ve bakım, üretim ve hasat konularında eğitilmesi yararlı olacaktır. Örneğin hayat boyu öğrenme programları kapsamında, çaylık oluşturma ve hasat modülü yer almaktadır. Bu modülün aktifleştirilmesi, sistemde kayıtlı üretici olarak gözüken tüm üreticilerin eğitim alınması yararlı olacaktır. Yenilikler, gelişmeler ve uygulamalar hususundaki işlemlerin sahada aktif olarak üreticilerle birlikte yapılması ve onlarında katılımının sağlanması, üreticiye bu işlemlerinin devamlılığının olacağı hususunda güvenin verilmesi de olumlu katkı olarak karşımıza çıkacaktır. Üreticilerden elde edilecek bilgiler, çalışanlarının görüşlerinin alınması, bu uygulamanın teşviki ve sürdürülebilirliği iş sağlığı ve güvenliği organizasyonunun canlı bir yapıya kavuşturabilir (Parlak vd., 2020).

Çay bahçelerinde yabani otla mücadele sırasında ergonomik riskler ortaya çıktığı gibi yabani otlar ve dikenler nedeniyle alerji, tahriş ve yaralanma; yabani hayvanlar (yılan, kene, örümcek, yabani arı, eşek arısı vb.) karşılaşma durumunda ise zehirlenme, yaralanma veya ölüm gibi durumlar ortaya çıkabilmektedir. Çay bahçelerinde çalışanların karşısına çıkan yabani ot ve zararlı hayvanların listesinin hazırlanması, bunların özellikleri, etkileri, bunlardan korunma gibi hususlarda üretici ve çalışanların eğitiminin sağlanması gerekmektedir. Ayrıca çalışmalar esnasında mevsim şartlarına uygun giysiler ve uygun eldiven kullanımının sağlanması yararlı olacaktır.

Çay bahçelerinin yöreye özgü coğrafi yapı nedeniyle engebeli oluşu, üreticiler tarafından araziden en fazla şekilde yararlanma arzusu, bahçelerin miras yoluyla bölünmesi, arazi sahipleri arasındaki anlaşmazlıklar ve kavgalar, bahçe kurulumu açısından eski usulde devam edilmesi, bahçelerin evlere uzak oluşu, toplama ve taşıma işlerinin uzun ve yorucu olması, sık tekrarlanan işlerin yapılması, çalışma süresinin uzun olması, bahçe yapısından dolayı sürekli eğik olarak çalışılması ve çalışanların aşırı güç sarf etmeleri gibi pek çok etken çay toplama işlerinde olumsuzluk olarak karşımıza çıkmaktadır. Üreticinin topladığı çayı kime ve ne şartlarda satacağı, çay alım yerlerinin uygunluğu, çay toplama için işçi bulup bulamayacağı, mevsimin çay bahçesindeki ürüne olan etkisi (kurak mevsim çayın yanması, geç olması; yağmurlu mevsim çayın erken ve gür olması, toplanmaması durumunda tazeliğini kaybetmesi), iklimsel özelliklerin çalışanlar üzerindeki etkisinden de söz edilmesi gerekmektedir. Tüm bu etkenler çalışma şekli üzerinde direkt olarak etki etmektedir.

Çaylık kurulumunda modernizasyonun olumlu katkıları olabilecektir. Modernizasyon sayesinde makineli toplama ve taşıma imkânı ortaya çıkabilir. Bahçelere ulaşım kolaylaşır, toplanan üründe kayıplar en aza indirilebilir ve üretimde verimlilik ve sürdürülebilirlik sağlanabilir. Belirli bir dizayn ve sisteme göre kurulan bahçe sayesinde toprak verimli kullanılabilir. Görünümün güzelleştirilmesi sonucu tarım turizmi gibi ilave bir katk1 sağlanabilir.

Çalışanlar üzerinde etkili olan psikososyal riskler; çalışma şartlarının zorluğu, yapılan işin temposunun yüksek olması, çalışma saatlerinin düzensiz ve uzun olması, aynı çalışma şekliyle (monoton) uzun süre çalışma, çevresel etkenler, çay toplama şekli, iş güvencesi ve sürekliliğinin olmaması, sigorta gibi sosyal hakların olmaması, elde edilen gelir ve dağılımı hakkındaki sorunlar, yapılan işin geleceğe dönük bir gelişim sağlamaması, çalışma süresi boyunca sosyal veya fiziksel olarak etraftan izole olunması, aile içi veya toplayıcılar arsındaki anlaşmazlıklar 
olarak karşımıza çıkabilmektedir. Bunlar da çalışanlar üzerinde etki ederek, çeşitli sorunlar; yorgunluk, sinirlilik, bezginlik, stres vb. olumsuzluk olarak kendini gösterebilir.

Yaşanan covid-19 pandemi süreci çay toplama işlemlerinde sorunların yaşanmasına sebep olmuştur. Geneli bölge dişında olan çay toplayıcı aileler bahçelerine ulaşmakta sorunlar yaşamıştır. İŞKUR devreye girerek çay bahçelerinde çalışacak işçi arayışına girmiştir. Bölgede kalan öğrencilerin çay işçisi olarak değerlendirilmesi durumu da düşünülmüştür. Bu durum profesyonel anlamda çay toplama işleri ile uğraşacak organizasyonların kurulabileceği düşüncesini temel oluşturmaktadır. Profesyonel olarak çay tarımı işleri ile uğraşacak firmaların kurulması, görev alacak insanların daha iyi sosyal haklardan yararlanması, çalışmaların yıl içine yayılarak daimi bir çalışma sürecinin oluşturulması değerlendirilebilir.

\section{Sonuç}

Yörenin önemli geçim kaynağı ve tarımsal faaliyeti olan çay toplama işlemlerinde devlet kontrolünde, özel sektörle işbirliği içerisinde, toplanan çayların zamanında ve belirli bir fiyat aralığında alınması, üreticinin bakım, gübreleme, üretim ve hasat aşamaları için düzenli olarak eğitilmesi ve bilinçlendirilmesi önem arz etmektedir.

Çay ile ilgili araştırmalar sürdürülürken bu işleri yapacak kişilerin, ailelerin sosyal, kültürel ve ekonomik olarak değerlendirilmeleri ve desteklenmeleri adına da çalışmalara ağırlık verilmelidir. Üretilen çayın değerinin artırılması, yeni hasat teknikleri, modern bahçe kurulumu veya eski bahçelerin gençleştirilmesi esnasındaki uygulamalar vb. etkenlerin elde edilecek geliri artırabileceği ve bunun üreticiler üzerinde pozitif etki yapabileceği üzerinde durulmalıdır.

Çay üretim bahçelerinin modernizasyonunun sağlanması, toplama işlerinde otomasyon ve mekanisayonun gelişmesine katkıda bulunabilir. Ayrıca taşıma, bakım ve ulaşımın daha kolay, ucuz bir şekilde gerçekleştirilmesine imkân sağlayabilir. Tüm bunlarla birlikte çalışanları zorlayan çalışma şartları, sık tekrarlı işler, ergonomik olarak uygun olmayan duruşlar, zorlu taşıma işleri, aşırı güç sarfiyatı gibi hususlarda iş sağlığı ve güvenliğinin daha da uygun noktalara gelmesi sağlanabilir.

\section{Kaynaklar}

Abac1, N.İ., Keskin, E. Ve Demiryürek, K., (2020). Innovation Decision Making Process in Organic Tea Agriculture: The Case of Rize District, Turkey, Black Sea Journal of Public and Social Science 3(1): 22-30

Ahmmed, F. and Hossain, Md.I. (2016). A Study Report on Working Conditions of Tea Plantation Workers in Bangladesh, ILO Country Office for Bangladesh, ISBN 978-984-34-1270-6

Alikılıç, D., (2016). Çay’ın Karadeniz Bölgesi İçin Önemi Ve Tarihi Seyri, Karadeniz İncelemeleri Dergisi, 2016; (21): 269-280

Arjantin'de Modern Hasat, https://www.finlays.net/about-us, Erişim Tarihi:24.01.2021

Aslanyürek, S., (2019). Çay Tarımı Çalışanlarında İş Sağlığı Ve Güvenliği Eğitiminin Fiziksel Ve Ergonomik Tehlikelerle İlgili Bilgi Düzeylerine Etkisi, Türkiye Cumhuriyeti, Karadeniz Teknik Üniversitesi, Sağlık Bilimleri Enstitüsü, Halk Sağlığı Anabilimdalı, Yüksek Lisans Tezi ss:3-46

Akbulut, M, Bakoğlu, N . (2017). Çay Üretiminde Hasat Ve Hasat Sonrasında Karşılaşılan Sorunlar Ve Çözüm Önerileri. Meyve Bilimi, Özel Sayı (Sempozyum), . Retrieved from https://dergipark.org.tr/tr/pub/meyve/issue/31361/614741

Aksüt, G., Eren, T., Tüfekçi, M., (2020). Ergonomik Risk Faktörlerinin Sınıflandırılması: Bir Literatür Taraması, Ergonomics 3(3), 169 - 192, 2020 DOI: 10.33439/ergonomi.773896

Bıçakçı, M. (b.t.). Denetimsiz Teleferikler Can Almaya Devam Ediyor! https://www.mmo.org.tr/sites/default/files/gonderi_dosya_ekleri/00a2131633b6106_ek.pdf

Chairman, S. K., (2005). Cultivation of Japanese Green Tea, World Green Tea Association, http://www.ocha.net/english/cup/pdf/14.pdf , Erişism Tarihi:24.01.2021

Çay Bahçesi Kulübesi, https://pixabay.com/tr/photos/çay-tarlası-kulübe-rize-countrside-1785803/, Erişim Tarihi:24.01.2021

Çay Toplama ve Taşıma Sepeti, https://www.mutfakmagazin.com/2020/04/06/caydan-covid-19-atagi-bir-cayhikayesi/, Erişim Tarihi:24.01.2021 
Çay Toplama ve Taşıma Sepeti, http://www.madeinturkeydergisi.com/2018/05/30/cay-ureticisinin-yuzu-fiyatartisiyla-guldu/, Erişim Tarihi:24.01.2021

Çay Toplama Makas1, http://biriz.biz/cay/turkcay.htm, Erişim Tarihi:24.01.2021

Çayeli Haremtepe Çay Bahçesi- Modern Bahçesi, (https://www.ntv.com.tr/galeri/seyahat/sosyal-medyadaunlenen-rizedeki-cay-bahcesi-turist-akinina-ugruyor,_6j0jjF69kyzWrmbqwjZ3g/0FeBC68BykmyZ1rsQPuR7g, Erişim Tarihi:24.01.2021

ÇAYKUR, Atatürk Çay ve Bahçe Kültürleri Araştırma Enstitüsü Müdürlüğü, http://www.caykur.gov.tr/Arge/Pages/Tarihce.aspx?ParentId=56, Erişim Tarihi:24.01.2021

ÇAYKUR, Kurumsal, http://www.caykur.gov.tr/Pages/Kurumsal/KurumHakkinda.aspx?ItemId=6

ÇAYMER, Rize Çay Araştırma ve Uygulama Merkezi’nin Kurulması Teknik Yardım Projesi, Rize Çay Araştırma ve Uygulama Merkezi İş Planı, Aktivite C1.2, Mart 2018

ÇAYMER, Çay Üretimine dair Uluslararası En İyi Uygulamaların Tespitine dair Araştırma Raporu, Faaliyet C2.1.4.1, Haziran 2018

ÇAYMER, Kurumsal, https://www.caymer.com.tr/, Erişim Tarihi:24.01.2021

Çin’de Örnek Çay Bahçesi, http://biriz.biz/cay/china.htm, Erişim Tarihi:24.01.2021

ÇSGB, Tarımda İş Sağlığı ve Güvenliği Rehberi, https://www.ailevecalisma.gov.tr/medias/4604/rehber27.pdf, Erişim Tarihi:24.01.2021

Devlet Planlama Teşkilatı (DPT), 1977. Dördüncü Beş Yıllık Kalkınma Planı, Yaş Çay ve Çay Sanayii, Özel İtisas Komisyonu Raporu, Yayın No. DPT: 1577 - ÖİK: 264, Ankara

Devlet Planlama Teşkilatı (DPT), 2001. Sekizinci Beş Yıllık Kalkınma Planı, Gıda Sanayii Özel İhtisas Komisyonu Raporu, Çay Sanayii Alt Komisyon Raporu, ISBN 975 - 19 - 2883-4, Ankara

Doğanay, S. (2011). Trabzon'da, Çay Tarımının Coğrafi Esasları. Doğu Coğrafya Dergisi, 11 (16) , 89-111. Retrieved from https://dergipark.org.tr/tr/pub/ataunidcd/issue/2441/31133

Durmuş, H., (2020). Çay Endüstrisinde İş Sağlığı Ve Güvenliği Açısından Risk Değerlendirmesi, Marmara Üniversitesi, Fen Bilimleri Enstitüsü, İş Güvenliği Anabilim Dalı, Yüksek Lisans Tezi

Endonezya'da Örnek Çay Bahçesi, https://upload.wikimedia.org/wikipedia/commons/c/cc/Tea_plantation_in_Ciwidey\%2C_Bandung_2014-0821.jpg, Erişim Tarihi:24.01.2021

Engin, F., (2017). Observations on Working Conditions Of Georgian Workers Who Work in Tea Agriculture, Fiscaoeconomia 2017, Vol.1(3) 1-13

Eraydın, C., Tezcan, B., Koç, Z., (2019). Hasta Düşmelerinin Değerlendirilmesinde Balık Kılçı̆̆ı Yöntemi İle Kök Neden Analizi, Journal of Health and Nursing Management. 2019; 6(3): 266-272 | DOI: 10.5222/SHYD.2019.82905

Eski Çay Bahçesi, https://tr.pinterest.com/dutxuri/_saved/, Erişim Tarihi:24.01.2021

Gönül, G., Aydın, H., (2017). Doğu Karadenizde Çay Tarımı ve Çay Ekonomisi, T.C. Avrasya Üniversitesi, Mühendislik Mimarlık Fakültesi, Gıda Mühendisliği Bölümü, Bitirme Projesi, Trabzon

Gökalp, H , Çeper, Ş . (1990). Yeşil Çay Üretim Teknolojisi ve Ülkemizde Yeşil Çay Üretimi. Gıda, 15 (6), . Retrieved from https://dergipark.org.tr/tr/pub/gida/issue/6916/92421

Güneroğlu, N., Acar, C . (2016). Landscape value of the tea (Camellia sinensis) areas. Artvin Çoruh Üniversitesi Orman Fakültesi Dergisi, 17 (1), 38-51 . DOI: 10.17474/acuofd.01389

Hürriyet, (2018). 2,5 yapraklı organik yeşil çaya 'inovasyon' ödülü, https://www.hurriyet.com.tr/yerelhaberler/trabzon/merkez/2-5-yaprakli-organik-yesil-caya-inovasyon-odu-40961529, Erişim Tarihi:24.01.2021

ILO, (2011). Safety and health in agriculture. ILO code of practice. International Labour Office - Geneva. ISBN 978-92-2-124971-9 (web pdf)

ILO, (2018). Future of Work for Tea Smallholders in Sri Lanka, ILO Country Office for Sri Lanka and the Maldives. - Colombo, ISBN: 978-92-2-031322-0 (web pdf) 
Iqbal, Mohammad \& Karim, M.A. \& Misbah, Syed \& Ahmed, Imtiaz \& Akhter, Salma \& Shamsuzzoha, Ahm. (2016). Study of occupational health hazards of selected tea gardens in Bangladesh.

İnci, N., (2016). İSG Proje Yönetimi ve Acil Durum Planı, Gedik Üniversitesi, Ders Notu, https://www.nurdogan.net/balik_dosyalar/7A-1505133-Balik_Kilcigi_R0B.pdf, Erişim Tarihi:24.01.2021

Japonya'da Örnek Çay Bahçesi, https://melhadtea.com/blog/japanese-tea-farm, Erişim Tarihi:24.01.2021

Japonya'da Modern Çay Hasadı, https://www.instagram.com/justteayourself/, Erişim Tarihi:24.01.2021

Karabacak, V., (2017). Çay Ve Fındık Tarımı Çalışanlarında İş Sağlığı Güvenliği Risklerinin Değerlendirilmesi ve Rehber Geliştirme Çalışması. T.C. Karadeniz Teknik Üniversitesi, Tıp Fakültesi, Halk Sağlığı Anabilim Dalı, Uzmanlık Tezi, Trabzon

Kaya, M. ve Özgülnar, N., (2015). Mevsimlik (Gezici/Geçici) Tarım İşçilerinin İki Yerleşim Birimindeki Yaşam Koşulları Ve Sağlık Durumlarına Niteliksel Bakış, Turk J Public Health 2015;13(2)

Koday, S., (2000). Türkiye Çay Tarım Alanlarının Dağılışı ve Çay Üretimimizdeki Gelişmeler, Türk Coğrafya Dergisi, Say1:35, s.321-346, İstanbul

KTU, (2017). Çay Tarımı Çalışanlarında İş Sağlığı ve Güvenliği Rehberi, ISBN:978-975-6983-93-5

MEB, (2014). Çaylık Oluşturma Ve Hasat Modülü, T.C. Millî Eğitim Bakanlığı, Hayat Boyu Öğrenme Genel Müdürlüğ̈̈

Milliyet, 2014. Çaykur Tarım İlacı Kullanan Üreticinin Çayını Almayacak, https://www.milliyet.com.tr/yerelhaberler/rize/caykur-tarim-ilaci-kullanan-ureticinin-cayini-almayacak-10253063, Erişim Tarihi:24.01.2021

Mirbod, Seyed Mohammad \& FUJITA, Setsuya \& MIYASHITA, Kazuhisa \& INABA, Ryoichi \& IWATA, Hirotoshi. (1995). Some Aspects of Occupational Safety and Health in Green Tea Workers.. Industrial health. 33. 101-17. 10.2486/indhealth.33.101.

NTV, (2020). Benzinli çay toplama yasak, https://www.ntv.com.tr/turkiye/benzinli-hasat-makinelerineyasak,1Ivx3107gku6Pm2S6iCu-g

Önal, İ. (2009). Sırtta Taşınan Çay Gübreleme Makinesi Prototipi. Tarım Makinaları Bilimi Dergisi, 5 (1) , 115 124. Retrieved from https://dergipark.org.tr/tr/pub/tarmak/issue/11547/137571

Önçırak, M., (2019). Çay Sektörü Ve Türkiye Ekonomisi, T. C. Bursa Uludağ Üniversitesi, Sosyal Bilimler Enstitüsü, İktisat Anabilim Dalı, Yüksek Lisans Tezi, Bursa

Parlak, T , Barışık, T , Yalçın, F . (2020). Gıda Ürünleri İmalatında Çalışan Personellerin İş Sağlığı ve Güvenliği Hakkındaki Farkındalık Durumlarının Tespiti Üzerine Bir Araştırma. OHS ACADEMY , 3 (1) , 13-27 . DOI: 10.38213/ohsacademy.691458

PHIRI, Y. V. A., KUMWENDA, S., \& TAULO, D. (2011). Knowledge, Attıtudes and Practıces Towards Occupational Health and Safety Among Tea Pluckers: A Case Study of Eastern Produce Malawi- Esperanza Estate in Mulanje.

Recep Tayyip Erdoğan Üniversitesi,(2018). Çay İle İlgili Çalışmalar, ISBN: 978-605-9072-16-8 Rize

Recep Tayyip Erdoğan Üniversitesi,(2020). Çay Hasadı, Recep Tayyip Erdoğan Üniversitesi Çay İhtisaslaşma Koordinatörlüğü, Rize

Recep Tayyip Erdoğan Üniversitesi, Recep Tayyip Erdoğan Üniversitesi Çay ve Çay Ürünleri Uygulama ve Araştırma Merkezi Yönetmeliği, Resmi Gazete Tarih: 9 Ekim 2017, Resmî Gazete Sayı: 30205

Sırtta Taşınan Çay Kesme Motoru, https://www.hepsiburada.com/cay-toplama-makinasi-pm-hrarsht2600y, Erişim Tarihi:24.01.2021

Tatoğlu., M. (2019). Çay Sektöründe Mevsimlik Tarım İşçiliği ve Gürcistan Uyruklu Kişilerin İletişim Sorunları, International Social Sciences Studies Journal, 5(36):2942-2946.

Tekeli, S . (2014). Rize'de çay yetiştirmenin tabii esasları. Türk Coğrafya Dergisi , 0 (2) , 213-240 . Retrieved from https://dergipark.org.tr/tr/pub/tcd/issue/21247/227964

Teleferik, http://www.mmorize.org/mmo_rize_haber15.htm, Erişim Tarihi:24.01.2021 
Toklu, İ, Ustaahmetoğlu, E. (2016). Tüketicilerin Organik Çaya Yönelik Tutumlarını ve Satın Alma Niyetlerini Etkileyen Faktörler: Bir Alan Araştırması. Uluslararası Yönetim İktisat ve İşletme Dergisi, 12 (29) , 41-61. DOI: 10.17130/ijmeb.20162922022

Uzun, A. Y., (2019). Çay Tarımında Kadın Emeği: Hopa Örneği, T.C. Ordu Üniversitesi, Sosyal Bilimler Enstitüsü, Çalışma Ekonomisi Ve Endüstri İlişkileri Anabilim Dalı, Ordu

Uzun Mesafeli Taşımalar, http://rizeazaklihoca.blogspot.com/2008/07/azaklihoca-ky-ay-baheleri-aytoplama_30.html, Erişim Tarihi:24.01.2021

Yağışlar Nedeniyle Oluşan Heyelan, https://www.sabah.com.tr/trabzon/2020/08/16/trabzonun-of-ve-hayratilcelerindeki-selden-en-fazla-zarari-cay-bahceleri-gordu, Erişim Tarihi:24.01.2021

Yaş Çay Alım Yeri, https://www.nextvery.com/cay-nasil-toplanir-cay-kesme-motoru-nedir-kurt-cay-iscilerigurculerin-yerini-alabilecek-mi/, Erişim Tarihi:24.01.2021

Yormaz, E . (2018). Rize Gazetesine Göre Rize'de Ekonomik Durum (1931-1942) . Karadeniz Araştırmaları Enstitüsü Dergisi, 4 (5) , 121-139. DOI: 10.31765/karen.438362

\section{Conflict of Interest / Çıkar Çatışması}

Yazarlar tarafından herhangi bir çıkar çatışması beyan edilmemiştir.

No conflict of interest was declared by the authors 